\title{
PARTISIPASI MASYARAKAT DAN STAKEHOLDER DALAM PENYELENGGARAAN PROGRAM CORPORATE SOCIAL RESPONSIBILITY (CSR) DAN DAMPAKNYA TERHADAP KOMUNITAS PERDESAAN
}

\author{
Society and Stakeholder Participation in Corporate Social Responsibility (CSR) Program and the \\ Impact of Rural Community
}

Isma Rosyida*) dan Fredian Tonny Nasdian

Departemen Sains Komunikasi dan Pengembangan Masyarakat, Fakultas Ekologi Manusia, IPB

*)Email : ismarosyida@gmail.com

Diterima 10 Februari 2011 / Disetujui 30 Maret 2011

\begin{abstract}
Empowerment is road to participation and participation determine social and economical community development program's impacts. Generally, this research aims to identifiy the correlation between participation level of society and stakeholders in holding Corporate Social Responsibility program of Geothermal Corporation through Micro Finance Board and its impact to the society's social and economical condition. This research was concerned to see the implementation of Community Based Micro Finance Program in Kabandungan District by holding LKMS Kartini. The subjects of this research were the society of Cihamerang Village, including its local government and local community, also corporate staffs. Methodes which are implied in this reseach consist of quantitative and qualitative study. Sample taken as many as fourty-five respondents who represent Cihamerang Village community, with the informant as many as nine persons. Results of this research shows that every stakeholders have different type and degree of participation. The higher micro finance board member's participation level in every steps of program implementation, the higher social and economical impacts will be got.
\end{abstract}

Keywords: Corporate Social Responsibility (CSR), Community Development, Society and Stakeholder Participation Level, Social and Economical Impacts

\section{PENDAHULUAN}

\section{Latar Belakang}

Perusahaan sebagai sebuah sistem, dalam keberlanjutan dan keseimbangannya tidak dapat berdiri sendiri. Keberadaan perusahaan dalam lingkungan masyarakat membawa pengaruh bagi kehidupan sosial, ekonomi, serta budaya. Dalam perjalanannya, aktivitas yang dilakukan oleh perusahaan bersinggungan, baik secara langsung maupun tidak langsung dengan masyarakat dan lingkungan. Oleh karena itu, perusahaan perlu mengingat dan memperhatikan aspek sosial budaya. Salah satunya adalah dengan membina hubungan baik yang bersifat reciprocal (timbal balik) dengan stakeholder-stakeholder lain, baik pemerintah, swasta, maupun dari berbagai tingkatan elemen masyarakat. Hubungan baik ini dapat dibentuk dari adanya interaksi antar stakeholder dalam kaitannya dengan penyelenggaraan program CSR (Corporate Social Responsibility).

Perusahaan Geothermal di Gunung Salak merupakan perusahaan yang mendayagunakan energi panas bumi terbesar di dunia. Panas bumi adalah sumber daya alam yang dapat diperbaharui dan digunakan sebagai pembangkit listrik melalui pemanfaatan daya alami uap bumi. Sebagai bukti profesionalisme dan tanggung jawab sosial perusahaan, Perusahaan Geothermal menyelenggarakan program CSR (Corporate Social Responsibility) yang mencakup tiga area kritis, yakni kebutuhan dasar, pendidikan dan pelatihan, serta pengembangan usaha kecil mikro. CSR yang diselenggarakan oleh Perusahaan Geothermal merupakan bagian dari strategic plan perusahaan, yang mana fokus pelaksanaannya berorientasi pada penciptaan pertumbuhan ekonomi melalui capacity building dan investasi masyarakat.

Penting untuk melihat sejauhmana implementasi dari program pengembangan masyarakat (Community Development) dalam kaitannya dengan partisipasi seluruh stakeholder yang pada akhirnya membawa dampak bagi komunitas perdesaan. Pada dasarnya keberhasilan suatu program CSR, salah satunya berkaitan dengan bagaimana program CSR tersebut dapat berpengaruh secara signifikan dan pada akhirnya membawa dampak positif terhadap kehidupan komunitas disekitar wilayah 
perusahaan. Oleh karena itu, hal yang akan menjadi pertanyaan secara garis besar dari penjelasan diatas yakni Bagaimana tingkat partisipasi masyarakat dan stakeholder dalam penyelenggaraan program CSR dengan dampak sosial ekonomi komunitas perdesaan?

\section{Perumusan Masalah}

Konsep Triple Bottom Line yakni Sosial (People), Lingkungan (Planet), dan Ekonomi (Profit) yang diperkenalkan oleh John Elkington pada tahun 1997 melalui bukunya "Cannibals with Forks, The Triple Bottom Line of Twentieth Century Business", menjelaskan keterkaitan antara tujuan perusahaan dengan keberadaan masyarakat dan lingkungan penting untuk diperhatikan. Konsep tersebut juga menyangkut peran dan fungsi dari stakeholder sebagai bagian dari elemen people dalam konsep triple bottom line. Stakeholder dalam peran dan fungsinya mendukung penyelenggaraan program CSR, dapat dilihat dari sejauhmana keterlibatannya dalam setiap tahapan penyelenggaraan program. Oleh karena itu, dapat dirumuskan bahwa: Bagaimana tingkat partisipasi stakeholder (pemerintah, masyarakat, swasta) dalam penyelenggaraan program CSR?

Untuk mengetahui sejauhmana komitmen perusahaan yang diwujudkan melalui implementasi program CSR, salah satunya dapat dilihat melalui penyelenggaraan program Community Development (Pengembangan Masyarakat). Penting halnya melihat pengaruh implementasi program tersebut terhadap komunitas lokal, khususnya bagi anggota kelompok simpan pinjam sebagai salah satu subjek pelaksana program, hingga sejauh mana implementasi tersebut dapat membawa dampak baik positif, maupun negatif bagi komunitas pedesaan. Kedua aspek tersebut mengkonstruksi pertanyaan utama dalam penelitian ini yaitu Bagaimana hubungan antara tingkat partisipasi anggota kelompok simpan pinjam LKMS Kartini dalam penyelenggaraan program CSR dengan dampak sosial komunitas perdesaan dan bagaimana hubungan antara tingkat partisipasi anggota kelompok simpan pinjam LKMS Kartini dalam penyelenggaraan program CSR dengan dampak ekonomi komunitas perdesaan?

\section{Tujuan Penelitian}

Tujuan utama penelitian ini yaitu untuk menganalisis tingkat partisipasi stakeholder dalam penyelenggaraan program CSR dan hubungannya dengan dampak sosial ekonomi. Adapun tujuan utama tersebut dapat dijawab melalui tujuan-tujuan khusus penelitian, yakni :

1. Menganalisis tingkat partisipasi stakeholder (pemerintah, masyarakat, swasta) dalam penyelenggaraan program CSR.

2. Menganalisis hubungan antara tingkat partisipasi anggota kelompok simpan pinjam LKMS Kartini dalam penyelenggaraan program CSR dengan dampak sosial komunitas perdesaan.

3. Menganalisis hubungan antara tingkat partisipasi anggota kelompok simpan pinjam LKMS Kartini dalam penyelenggaraan program CSR dengan dampak ekonomi komunitas perdesaan.

\section{Kegunaan Penelitian}

Hasil penelitian ini diharapkan dapat memberi manfaat bagi para pihak yang berminat maupun yang terkait dengan masalah CSR, khususnya kepada:

1. Peneliti yang ingin mengkaji lebih jauh mengenai CSR dalam kaitannya dengan analisis dampak implementasi program CSR, termasuk bagi peneliti yang ingin melakukan penelitian lanjutan dan pengembangan dengan penelitian terkait yang sudah ada sebelumnya.

2. Kalangan akademisi, dapat menambah literatur dalam melakukan kajian mengenai CSR.

3. Kalangan non akademisi, pemerintah, maupun swasta dapat bermanfaat sebagai sebuah bahan pertimbangan dalam penerapan CSR yang berbasiskan pengembangan masyarakat.

\section{PENDEKATAN KONSEPTUAL}

\section{Tinjauan Pustaka}

\section{Corporate Social Responsibility}

Konsep CSR (Corporate Social Responsibility) memiliki beberapa definisi yang dikemukakan oleh banyak ahli. Definisi CSR berasal dari konsep dan pemikiran yang dicetuskan oleh John Elkington (1997) dalam bukunya yang berjudul "Cannibals with Forks, The Triple Bottom Line of Twentieth Century Business", dimana dalam buku tersebut Elkington mengemukakan konsep "3P" (profit, people, dan planet) yang menerangkan bahwa dalam menjalankan operasional perusahaan, selain mengejar profit/keuntungan ekonomis sebuah korporasi harus dapat memberikan kontribusi positif bagi people (masyarakat) dan berperan aktif dalam menjaga kelestarian lingkungan (planet) (Wibisono, 2007). Menurut ISO 26000 dalam Suharto (2008), CSR adalah tanggung jawab sebuah organisasi terhadap dampakdampak dari keputusan-keputusan dan kegiatankegiatannya pada masyarakat dan lingkungan yang diwujudkan dalam bentuk perilaku transparan dan etis yang sejalan dengan pembangunan berkelanjutan dan kesejahteraan masyarakat, mempertimbangkan harapan pemangku kepentingan, sejalan dengan hukum yang ditetapkan dan norma-norma perilaku internasional, serta terintegrasi dengan organisasi secara menyeluruh.Telaah lebih lanjut atas berbagai literatur menunjukkan bahwa ada empat skema yang biasa dipergunakan untuk menjalankan tanggung jawab sosial perusahaan, yaitu (1) kontribusi pada program pengembangan masyarakat, (2) pendanaan kegiatan sesuai dengan kerangka legal, (3) partisipasi masyarakat dalam bisnis, dan (4) tanggapan atas tekanan kelompok kepentingan ${ }^{1}$. Wibisono (2007) mengemukakan perusahaan-perusahaan yang telah berhasil dalam menerapkan CSR menggunakan tahapan implementasi CSR sebagai berikut:

1. Tahap Perencanaan: Tahap ini terdiri dari tiga langkah utama, yaitu Awareness Building, CSR

${ }^{1}$ Jalal.2010.Masukan bagi Program PROPER Kementrian Lingkungan Hidup. Jakarta: Laboratorium Sosiologi Universitas Indonesia

52 Rosyida, Isma. et. al. Partisipasi Masyarakat dan Stakeholder dalam Penyelenggaraan Program Corporate Social Responsibility (CSR) dan Dampaknya terhadap Komunitas Perdesaan 
Assesment, dan CSR Manual Building. Awareness Building merupakan langkah awal untuk membangun kesadaran perusahaan mengenai arti penting CSR dan komitmen manajemen, upaya ini dapat dilakukan melalui seminar, lokakarya, dan lain-lain. CSR Assesment merupakan upaya untuk memetakan kondisi perusahaan dan mengidentifikasi aspek-aspek yang perlu mendapatkan prioritas perhatian dan langkah-langkah yang tepat untuk membangun struktur perusahaan yang kondusif bagi penerapan CSR secara efektif. Pada tahap membangun, CSR manual, dilakukan melalui benchmarking, menggali dari referensi atau meminta bantuan tenaga ahli independen dari luar perusahaan. Pedoman ini diharapkan mampu memberikan kejelasan dan keseragaman pola pikir dan pola tindak seluruh elemen perusahaan guna tercapainya pelaksanaan program yang terpadu, efektif, dan efisien.

2. Tahap Pelaksanaan: Pada tahap ini terdapat beberapa poin yang harus diperhatikan seperti pengorganisasian sumber daya, penyusunan untuk menempatkan orang sesuai dengan jenis tugas, pengarahan, pengawasan, pelaksanaan, pekerjaan sesuai dengan rencana, serta penilaian untuk mengetahui tingkat pencapaian tujuan.

3. Tahap Pemantauan dan Evaluasi: Tahap ini perlu dilakukan secara konsisten dari waktu ke waktu untuk mengukur sejauhmana efektivitas penerapan CSR sehingga membantu perusahaan untuk memetakan kembali kondisi dan situasi serta capaian perusahaan dalam implementasi CSR sehingga dapat mengupayakan perbaikan-perbaikan yang perlu berdasarkan rekomendasi.

4. Tahap Pelaporan: Pelaporan perlu dilakukan untuk membangun sistem informasi, baik untuk keperluan proses pengambilan keputusan maupun keperluan keterbukaan informasi material dan relevan mengenai perusahaan.

Ide mengelola hubungan dengan pemangku kepentingan (stakeholder) adalah hal mendasar bagi kebanyakan perusahaan, bahkan ide ini mewakili substansi dari bagaimana sebuah perusahaan dibangun dan dikelola, serta menjadi penting berkaitan dengan manajemen strategis secara khusus (Sukada, 2007). Stakeholders, yang jamak diterjemahkan dengan pemangku kepentingan adalah pihak atau kelompok yang berkepentingan, baik langsung maupun tidak langsung terhadap eksistensi atau aktivitas perusahaan, dan karenanya kelompok-kelompok tersebut mempengaruhi dan atau dipengaruhi oleh perusahaan (Saidi, 2004). Menurut Sukada (2007), pelibatan pemangku kepentingan ditentukan berdasarkan derajat relevansinya dengan keberadaan serta program yang akan diselenggarakan. Sukada (2007) menambahkan, semakin relevan pemangku kepentingan dengan kegiatan maupun aktivitas pengembangan masyarakat perusahaan, maka pelibatannya menjadi keharusan.

\section{Community Development}

Community Development (Pengembangan Masyarakat) sebagai salah satu dari tujuh isu CSR merupakan sarana aktualisasi CSR yang paling baik jika dibandingkan dengan implementasi yang hanya berupa charity, philantrophy, atau dimensi-dimensi CSR yang lain, karena dalam pelaksanaan pengembangan masyarakat terdapat prinsip-prinsip kolaborasi kepentingan bersama antara perusahaan dengan komunitas, adanya partisipasi, produktivitas, keberlanjutan, dan mampu meningkatkan perasaan solidaritas. Tanggung jawab sosial dapat diwujudkan melalui pengembangan potensi kedermawanan perusahaan. Kedermawanan perusahaan sesungguhnya adalah kedermawanan sosial dalam kerangka kesadaran dan komitmen perusahaan untuk melaksanakan tanggung jawab sosialnya (Saidi, 2003). Menurut Steiner (1994) dalam Nursahid (2006), terdapat sejumlah alasan mengapa perusahaan memiliki programprogram filantropik atau kedermawanan sosial, yaitu pertama, untuk mempraktikkan konsep "good corporate citizenship"; kedua, untuk meningkatkan kualitas lingkungan hidup; dan ketiga, untuk meningkatkan kualitas sumber daya manusia terdidik.

\section{Konsep Partisipasi}

Menurut Nasdian (2006), pemberdayaan merupakan jalan atau sarana menuju partisipasi. Sebelum mencapai tahap tersebut, tentu saja dibutuhkan upaya-upaya pemberdayaan masyarakat. Pemberdayaan memiliki dua elemen pokok, yakni kemandirian dan partisipasi (Nasdian, 2006_). Nasdian (2006) mendefinisikan partisipasi sebagai proses aktif, inisiatif diambil oleh warga komunitas sendiri, dibimbing oleh cara berfikir mereka sendiri, dengan menggunakan sarana dan proses (lembaga dan mekanisme) dimana mereka dapat menegaskan kontrol secara efektif. Titik tolak dari partisipasi adalah memutuskan, bertindak, kemudian mereka merefleksikan tindakan tersebut sebagai subjek yang sadar. Nasdian (2006) juga memaparkan bahwasanya partisipasi dalam pengembangan komunitas harus menciptakan peranserta yang maksimal dengan tujuan agar semua orang dalam masyarakat tersebut dapat dilibatkan secara aktif pada proses dan kegiatan masyarakat. Cohen dan Uphoff (1979) membagi partisipasi ke beberapa tahapan, yaitu sebagai berikut:

1. Tahap pengambilan keputusan, yang diwujudkan dengan keikutsertaan masyarakat dalam rapat-rapat. Tahap pengambilan keputusan yang dimaksud disini yaitu pada perencanaan dan pelaksanaan suatu program.

2. Tahap pelaksanaan yang merupakan tahap terpenting dalam pembangunan, sebab inti dari pembangunan adalah pelaksanaanya. Wujud nyata partisipasi pada tahap ini digolongkan menjadi tiga, yaitu partisipasi dalam bentuk sumbangan pemikiran, bentuk sumbangan materi, dan bentuk tindakan sebagai anggota proyek.

3. Tahap evaluasi, dianggap penting sebab partisipasi masyarakat pada tahap ini merupakan umpan balik yang dapat memberi masukan demi perbaikan pelaksanaan proyek selanjutnya. 
4. Tahap menikmati hasil, yang dapat dijadikan indikator keberhasilan partisipasi masyarakat pada tahap perencanaan dan pelaksanaan proyek. Selain itu, dengan melihat posisi masyarakat sebagai subjek pembangunan, maka semakin besar manfaat proyek dirasakan, berarti proyek tersebut berhasil mengenai sasaran.

Keseluruhan tingkatan partisipasi di atas merupakan kesatuan integratif dari kegiatan pengembangan perdesaan, meskipun sebuah siklus konsisten dari kegiatan partisipatoris mungkin dinilai belum biasa.

Partisipasi masyarakat menggambarkan bagaimana terjadinya pembagian ulang kekuasaan yang adil (redistribution of power) antara penyedia kegiatan dan kelompok penerima kegiatan. Partisipasi masyarakat tersebut bertingkat, sesuai dengan gradasi, derajat wewenang dan tanggung jawab yang dapat dilihat dalam proses pengambilan keputusan. Gradasi peserta dapat digambarkan dalam Tabel 1 sebagai sebuah tangga dengan delapan tingkatan yang menunjukkan peningkatan partisipasi tersebut (Arnstein 1986 dalam Wicaksono 2010):

Tabel 1. Tingkat Partisipasi Masyarakat menurut Tangga Partisipasi Arnstein

\begin{tabular}{|c|c|c|c|}
\hline $\begin{array}{c}\text { No } \\
\cdot\end{array}$ & $\begin{array}{l}\text { Tangga/Tingka } \\
\text { tan Partisipasi }\end{array}$ & $\begin{array}{l}\text { Hakekat } \\
\text { Kesertaan }\end{array}$ & $\begin{array}{c}\text { Tingkatan } \\
\text { Pembagian } \\
\text { Kekuasaan } \\
\end{array}$ \\
\hline 1. & $\begin{array}{l}\text { Manipulasi } \\
\text { (Manipulation) }\end{array}$ & $\begin{array}{l}\text { Permainan } \\
\text { oleh } \\
\text { pemerintah }\end{array}$ & \multirow[b]{2}{*}{$\begin{array}{l}\text { Tidak ada } \\
\text { partisipasi }\end{array}$} \\
\hline 2. & $\begin{array}{l}\text { Terapi } \\
\text { (Therapy) }\end{array}$ & $\begin{array}{l}\text { Sekedar agar } \\
\text { masyarakat } \\
\text { tidak } \\
\text { marah/sosiali } \\
\text { sasi }\end{array}$ & \\
\hline 3. & $\begin{array}{l}\text { Pemberitahuan } \\
\text { (Informing) }\end{array}$ & $\begin{array}{l}\text { Sekedar } \\
\text { pemberitahua } \\
\mathrm{n} \\
\text { searah/sosiali } \\
\text { sasi }\end{array}$ & \multirow{3}{*}{$\begin{array}{l}\text { Tokenism/seke } \\
\text { dar justifikasi } \\
\text { agar } \\
\text { mengiyakan }\end{array}$} \\
\hline 4. & $\begin{array}{l}\text { Konsultasi } \\
\text { (Consultation) }\end{array}$ & $\begin{array}{l}\text { Masyarakat } \\
\text { didengar, tapi } \\
\text { tidak selalu } \\
\text { dipakai } \\
\text { sarannya }\end{array}$ & \\
\hline 5. & $\begin{array}{l}\text { Penentraman } \\
\text { (Placation) }\end{array}$ & $\begin{array}{l}\text { Saran } \\
\text { Masyarakat } \\
\text { diterima tapi } \\
\text { tidak selalu } \\
\text { dilaksanakan }\end{array}$ & \\
\hline 6. & $\begin{array}{l}\text { Kemitraan } \\
\text { (Partnership) }\end{array}$ & $\begin{array}{l}\text { Timbal balik } \\
\text { dinegosiasika } \\
\mathrm{n}\end{array}$ & \multirow{3}{*}{$\begin{array}{l}\text { Tingkat } \\
\text { kekuasaan ada } \\
\text { di masyarakat }\end{array}$} \\
\hline 7. & $\begin{array}{l}\text { Pendelegasian } \\
\text { Kekuasaan } \\
\text { (Delegated } \\
\text { Power) }\end{array}$ & $\begin{array}{l}\text { Masyarakat } \\
\text { diberi } \\
\text { kekuasaan } \\
\text { (sebagian } \\
\text { atau seluruh } \\
\text { program) }\end{array}$ & \\
\hline 8. & $\begin{array}{l}\text { Kontrol } \\
\text { Masyarakat }\end{array}$ & $\begin{array}{l}\text { Sepenuhnya } \\
\text { dikuasai oleh }\end{array}$ & \\
\hline
\end{tabular}

\begin{tabular}{|l|l|l|l|}
\hline & $\begin{array}{l}\text { (Citizen } \\
\text { Control) }\end{array}$ & masyarakat & \\
\hline
\end{tabular}

Sumber: Arnstein (1969:217) dalam Wicaksono (2010)

Arnstein (1969) menyatakan bahwa partisipasi masyarakat identik dengan kekuasaan masyarakat (citizen partisipation is citizen power). Partisipasi masyarakat bertingkat sesuai dengan gradasi kekuasaan yang dapat dilihat dalam proses pengambilan keputusan.

\section{Konsep Modal Sosial}

Modal sosial adalah seperangkat nilai-nilai, norma-norma, dan kepercayaan yang memungkinkan sekelompok warga dapat bekerjasama secara efektif dan terkoordinasi untuk mencapai tujuan-tujuannnya (Putman,1993 dalam Suwartika, 2003). Uphoff (2000) dalam Suwartika (2003) membagi komponen modal sosial ke dalam dua kategori, yaitu pertama, kategori struktural yang dihubungkan dengan berbagai bentuk asosiasi sosial dan kedua, kategori kognitif dihubungkan dengan proses-proses mental dan ide-ide yang berbasis pada ideologi dan budaya. Komponen-komponen modal sosial (Uphoff, 2000 dalam Suwartika, 2003) tersebut diantaranya:

1. Hubungan sosial (jaringan); merupakan pola-pola hubungan pertukaran dan kerjasama yang melibatkan materi dan non materi. Hubungan ini memfasilitasi tindakan kolektif yang saling menguntungkan dan berbasis pada kebutuhan. Komponen ini termasuk pada kategori struktural.

2. Norma; kesepakatan-kesepakatan tentang aturan yang diyakini dan disetujui bersama.

3. Kepercayaan; komponen ini menunjukkan norma tentang hubungan timbal balik, nilai-nilai untuk menjadi seseorang yang layak dipercaya. Pada bentuk ini juga dikembangkan keyakinan bahwa anggota lain akan memiliki keinginan untuk bertindak sama. Komponen ini termasuk dalam kategori kognitif.

4. Solidaritas; terdapat norma-norma untuk menolong orang lain, bersama-sama, menutupi biaya bersama untuk keuntungan kelompok. Sikap-sikap kepatuhan dan kesetiaan terhadap kelompok dan keyakinan bahwa anggota lain akan melaksanakannya. Komponen ini termasuk dalam kategori struktural

5. Kerjasama; terdapat norma-norma untuk bekerjasama bukan bekerja sendiri. Sikap-sikap kooperatif, keinginan untuk membaktikan diri, akomodatif, menerima tugas dan penugasan untuk kemaslahatan bersama, keyakinan bahwa kerjasama akan menguntungkan. Komponen ini termasuk dalam kategori kognitif.

Menurut Djohan (2007), modal sosial yang ideal adalah modal sosial yang tumbuh di masyarakat. Modal sosial yang dimiliki seyogianya memiliki muatan nilai-nilai yang merupakan kombinasi antara nilai-nilai universal yang berbasis humanisme dan nilai-nilai pencapaian (achievement values) dengan nilai-nilai lokal.

\section{Konsep Dampak Program CSR}

54 Rosyida, Isma. et. al. Partisipasi Masyarakat dan Stakeholder dalam Penyelenggaraan Program Corporate Social Responsibility (CSR) dan Dampaknya terhadap Komunitas Perdesaan 
Min-Dong Paul Lee (2008) melakukan studi khusus terkait bagaimana jejak dan perkembangan mengenai teori tanggung jawab sosial perusahaan diulas secara detail dalam jurnalnya yang berjudul "A Review of the Theories of Corporate Social Responsibility: Its Evolutionary Path and the Road Ahead". Studi ini ditujukan untuk menunjukkan jejak evolusioner konseptual dari teori-teori tanggung jawab sosial perusahaan (CSR) dan untuk melihat refleksi implikasinya terhadap pembangunan. Restropeksi menunjukkan bahwa perkembangan tren telah menjadi sebuah rasionalisasi progresif dari konsep dengan sebuah fokus tertentu dalam ikatan lebih kuat terhadap tujuan finansial perusahaan. Telah banyak upaya dilakukan oleh berbagai pihak di dunia untuk menstimulasi pelibatan aktif masyarakat, bagaimana membangun kemitraan baik untuk mengatur hubungan dengan masyarakat dan lingkungan.

Jurnal Reporting on Community Impacts: A survey conducted by the Global Reporting Initiative, menambahkan bahwa peningkatan terjadi ketika upaya tersebut disusun secara strategis dan dikaitkan dengan kerangka internasional seperti halnya Millenium Development Goals (MDGs) (Dragicevic, 2008). Pada waktu yang sama, pertumbuhan atau peningkatan yang mengukur hasil dan memahami bagaimana CSR dapat memberikan nilai baik bagi perusahaan maupun bagi komunitas. Jalal (2010) mengemukakan bahwasanya praktik-praktik bisnis yang dilakukan oleh banyak perusahaan di Indonesia dalam berhubungan dengan masyarakat yang tinggal di sekitarnya belum dapat dibilang memadai, tampaknya kesimpulan itu tidak akan ditolak. Pertanyaan penting berkaitan dengan kondisi itu adalah bagaimana cara untuk mengetahui bahwa sebuah program pengembangan masyarakat oleh perusahaan telah dapat dianggap memadai. Jawaban tersebut sebenarnnya ada pada fungsi indikator keberhasilan. Indikator keberhasilan akan menjadi sangat penting manakala perusahaan hendak mengetahui kinerja program pengembangan masyarakatnya, atau hendak menyusun rencana strategik yang menginginkan tingkat kinerja tertentu.

\section{Kerangka Pemikiran}

Kerangka pemikiran penelitian ini mengacu pada tingkat keterlibatan atau partisipasi stakeholder dalam penyelenggaraan program Corporate Social Responsibility (CSR), yakni program pemberdayaan ekonomi lokal melalui pembentukan LKMS Kartini.

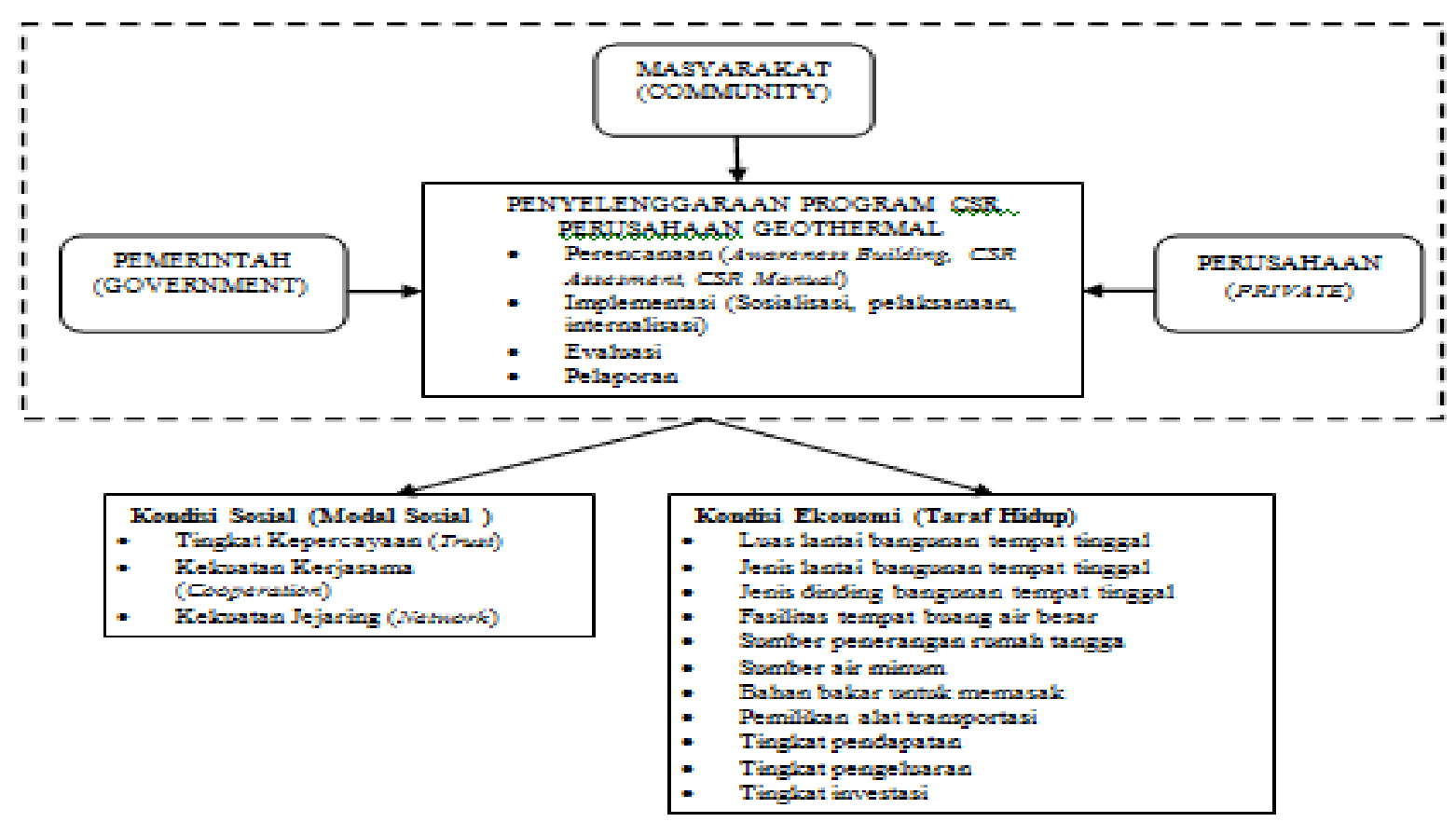

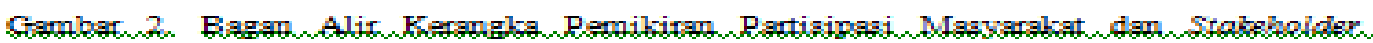

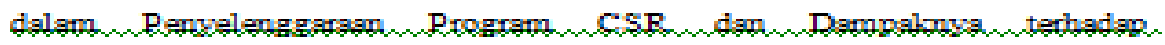
Komunitas. Perdesasn.

terjadi memperkuat pemahaman mengenai dampak dari kegiatan bisnis terhadap masyarakat dan lingkungan. Ada peningkatan kepentingan dari stakeholders kepada perusahaan untuk mengklarifikasi dan mendemonstrasikan dampaknya. Bagaimanapun juga, berdasarkan sebuah penelitian terkait dampak dari CSR pada perusahaan besar agar mampu melihat dampak secara umum, kasus bisnis, sikap bisnis, kesadaran dan praktik seharusnya juga mengetahui secara baik kebiasaan stakeholder, tetapi upaya untuk mengklarifikasi dampak pada hubungan terhadap manusia. Oleh karena itu, saat ini makin maraknya tren terhadap kepentingan yang lebih dari sebuah perusahaan dan stakeholder nya untuk
Bagaimana membentuk dan membina hubungan sinergis diantara stakeholder-stakeholder tersebut, hal ini merupakan salah satu tolak ukur dalam menilai keberhasilan dalam penyelenggaraan LKMS Kartini, yang mana salah satu kegiatannya adalah kelompok simpan pinjam. Oleh karena itu, stakeholder yang terdiri dari pemerintah (government), perusahaan (private), dan masyarakat (society) memiliki peran dalam keseluruhan tahapan penyelenggaraan program tersebut. Para stakeholder tersebut terkategori berdasarkan keberadaan dan tingkat kepetingannya sesuai dengan konsep pemangku kepentingan menurut Rhenald Khasali (2005) 
dalam Wibisono (2007), yakni pemerintah dan masyarakat sebagai stakeholder eksternal dan pihak swasta sebagai stakeholder internal. Sejauhmana keterlibatan para stakeholders dalam tahapan penyelenggaraan program tersebut digambarkan melalui tingkat partisipasi masing-masing stakeholder. Tingkat partisipasi menurut Cohen dan Uphoff (1979) terdiri dari empat kategori, yakni tingkat pengambilan keputusan (perencanaan), tingkat pelaksanaan, tingkat evaluasi, dan tingkat pemanfaatan hasil, namun pada penelitian ini hanya digunakan tingkatan pertama, kedua, dan ketiga. Dampak sosial terkait dengan bagaimana kekuatan modal sosial yang terbangun dalam masyarakat. Modal sosial dalam hal ini, sesuai dengan konsep modal sosial menurut Uphoff (2000) dalam Suwartika (2003) diukur dari tingkat kepercayaan, kekuatan jaringan, dan kekuatan kerjasama. Sedangkan dampak ekonomi dilihat dari tingkat pendapatan, tingkat pengeluaran, tingkat tabungan, dan juga taraf hidup masyarakat

\section{Hipotesis Penelitian}

Pada penelitian evaluasi ini, hipotesis disusun untuk menguji signifikansi tingkat partisipasi anggota kelompok simpan pinjam dengan dampak sosial dan dampak ekonomi. Hipotesis uji meliputi :

1. Semakin tinggi partisipasi anggota kelompok simpan pinjam LKMS Kartini dalam penyelenggaraan program CSR, maka semakin kuat modal sosial komunitas perdesaan.

2. Semakin tinggi tingkat partisipasi anggota kelompok simpan pinjam LKMS Kartini dalam penyelenggaraan program CSR, maka semakin tinggi taraf hidup komunitas perdesaan.

\section{METODE PENELITIAN}

\section{Lokasi dan Waktu Penelitian}

Penelitian dilakukan di Desa Cihamerang, Kecamatan Kabandungan, Kabupaten Sukabumi, sebagai salah satu penerima dan partisipan dalam Program Corporate Social Responsibility atau dalam hal ini disebut sebagai program Community Engagement. Program Community Based Micro Finance melalui pembentukan Lembaga Keuangan Mikro Syariah (LKMS) Kartini menjadi fokus dalam penelitian ini yang mencakup seluruh desa di Kecamatan Kabandungan, namun dalam penelitian ini hanya difokuskan ke Desa Cihamerang saja. Hal tersebut dikarenakan Desa Cihamerang memiliki jumlah tertinggi masyarakat yang menjadi anggota kelompok simpan pinjam LKMS Kartinidan anggota kelompok simpan pinjam di Desa Cihamerang tergolong aktif dan beberapa kelompok telah memperoleh pinjaman lebih dari satu putaran. Penelitian ini difokuskan untuk melihat sejauhmana partisipasi anggota kelompok simpan pinjam, berikut stakeholder terkait lain dalam penyelenggaraan program, dan hubungannya dengan dampak sosial ekonomi yang diperoleh oleh anggota tersebut. Penjajagan lokasi penelitian dilakukan pada bulan Juni hingga Agustus tahun 2010 yang terintegrasi dengan kegiatan KKP (Kuliah Kerja Profesi), sedangkan penelitian dimulai pada bulan Oktober dan berakhir pada bulan November akhir di tahun 2010.

\section{Pendekatan Penelitian}

Pendekatan yang dipilih dalam penelitian ini adalah pendekatan kuantitatif yang didukung oleh pendekatan kualitatif. Untuk penelitian kuantitatif digunakan metode survei. Kuesioner digunakan sebagai instrumen untuk mengumpulkan informasi dari responden. Metode survei ini digunakan untuk mendapatkan data terkait dengan hubungan antara tingkat partisipasi anggota kelompok LKMS Kartini dengan aspek dampak sosial masyarakat pemanfaat program CSR atau dalam hal ini anggota LKMS Kartini dan juga melihat hubungan antara aspek tingkat partisipasi anggota kelompok simpan pinjam LKMS Kartini dengan dampak ekonomi setelah implementasi program CSR. Metode studi kasus pada penelitian kualitatif adalah bersifat explanatory research untuk mengetahui bagaimana penyelenggaraan program CSR oleh Perusahaan Geothermal dalam setiap tahapan, baik perencanaan, pelaksanaan, evaluasi, dan pelaporan melibatkan berbagai stakeholder terkait dan juga menggali infomasi dampak penyelenggaraan program CSR tersebut terhadap kondisi sosial ekonomi anggota kelompok simpan pinjam LKMS Kartini.

\section{Teknik Pemilihan Responden dan Informan}

Terdapat dua subjek dalam penelitian ini, yaitu informan dan responden. Informan adalah pihak yang memberikan keterangan tentang diri sendiri, keluarga, pihak lain dan lingkungannya. Pemilihan informan dilakukan secara purposive dengan teknik snowball (teknik bola salju). Informan kunci yang dipilih adalah pihak Perusahaan Geothermal yang menangani bidang CSR, Departemen PGPA (Policy, Government, and Public Affair), dalam hal ini Community Engagement. Selain itu, tokoh masyarakat berserta masyarakat Desa Cihamerang, Kecamatan Kabandungan, Kabupaten Sukabumi yang mendapat manfaat dari program Community Engagement. Pemerintah setempat, yakni pemerintah Desa Cihamerang dan pemerintah Kecamatan Kabandungan juga menjadi informan kunci dalam penelitian ini. Untuk melengkapi data yang didapatkan dari informan kunci, diperlukan data dari informan-informan lainnya yang kemudian akan didiskusikan bersama informan kunci. Populasi dalam penelitian ini adalah seluruh rumah tangga masyarakat Desa Cihamerang yang menjadi anggota kelompok simpan pinjam LKMS Kartini, yakni dalam hal ini berjumlah 75 orang. Dari keseluruhan populasi, dibentuklah kerangka sampling yang berjumlah 54 orang dengan meliputi anggota kelompok simpan pinjam di dua dusun/kampung, yakni dusun/kampung Pasir Haur dan Pameungpeuk. Pemilihan kedua dusun tersebut didasarkan pada kriteria, dimana kelompok di dua dusun tersebut tergolong aktif mengadakan kumpulan setiap minggunya dan juga frekuensi putaran pinjaman modal yang sudah minimal dua kali dilakukan. Pengambilan sampel dari kerangka sampling dilakukan secara puposif, mengingat penelitian ini diarahkan untuk melihat dampak penyelenggaraan program sehingga responden yang dipilih merupakan anggota kelompok simpan pinjam yang sudah mengikuti dua kali putaran pinjaman modal. Selain itu, faktor frekuensi penyelenggaran kumpulan juga menjadi pertimbangan dalam pemilihan responden. Jumlah responden yang 
diambil dalam penelitian ini berjumlah 45 orang, yang terdiri dari 30 responden dari rumah tangga anggota kelompok simpan pinjam LKMS Kartini dan 15 responden pembanding dari rumah tangga non-anggota kelompok simpan pinjam LKMS Kartini. Responden sebanyak 30 orang dari kategori rumah tangga anggota kelompok simpan pinjam diambil dari kerangka sampling yang dengan pertimbangan bahwasanya tidak semua anggota kelompok simpan pinjam dalam kerangka sampling dapat berkomunikasi dengan baik dan dapat diwawancarai untuk diambil datanya.

\section{Jenis Data dan Teknik Pengumpulan Data}

Data primer dan data sekunder merupakan dua jenis data yang diperlukan dalam penelitian ini. Data primer merupakan data yang didapatkan dari hasil wawancara mendalam yang dilakukan terhadap informan dan juga penyebaran kuesioner kepada responden, di samping itu data primer juga diperoleh peneliti selama di lapangan melalui observasi, sedangkan data sekunder merupakan data yang diperoleh dari dokumen-dokumen tertulis baik yang berupa tulisan ilmiah ataupun dokumen resmi tentang instansi terkait. Teknik pengumpulan data yang digunakan untuk penelitian kuantitatif adalah dengan penyebaran instrumen pengumpulan data, yakni kuesioner.

Metode triangulasi merupakan metode yang dipilih untuk pengumpulan data kualitatif agar diperoleh kombinasi yang akurat berupa wawancara mendalam, pengamatan berperanserta dan penelusuran dokumen. Untuk menghindari adanya distorsi pesan, maka setelah melakukan wawancara mendalam dengan informan, peneliti menulis kembali hasil wawancara dalam bentuk catatan harian. Catatan harian atau catatan lapangan adalah isntrumen utama yang melekat pada metodemetode pengumpulan data kualitatif (Sitorus, 1998). Hasilnya dapat digunakan untuk menjelaskan gejala sosial yang berkaitan dengan penyelenggaraan program CSR.

\section{Teknik Pengolahan dan Analisis Data}

Teknik analisis data yang dilakukan adalah analisis data kualitatif dan kuantitatif. Data kualitatif baik primer maupun sekunder yang telah didapatkan akan diolah dan dianalisis secara kualitatif. Analisis data kuantitatif yang mengukur dampak implementasi program terhadap masyarakat akibat adanya program CSR, dilakukan melalui hasil penyebaran kuesioner kepada responden. Data yang diperoleh diolah dengan proses editing, coding, scoring, entry, cleaning, dan analisis data dengan menggunakan program microsoft excel dan SPSS 15.0 for Windows.

Untuk mengetahui hubungan antara tingkat partisipasi anggota kelompok simpan pinjam LKMS Kartini dan aspek dampak sosial penyelenggaraan program, serta hubungan antara keterlibatan dengan aspek dampak ekonomi dari implementasi program CSR digunakan uji korelasi rank spearman. Uji statistik ini dilakukan untuk melihat apakah terdapat hubungan antara tingkat partisipasi anggota kelompok simpan pinjam LKMS Kartini dalam setiap tahapan penyelenggaraan program, baik perencanaan, pelaksanaan, evaluasi, maupun pelaporan dengan dampak sosial dan ekonomi anggota. Disamping itu, melihat perbandingan antara masyarakat pemanfaat program dan masyarakat yang bukan pemanfaat program untuk mengetahui dampak dari implementasi program bagi masyarakat digunakan tabel frekuensi untuk melihat persentase.

\section{GAMBARAN UMUM LOKASI}

\section{Profil Desa Cihamerang}

Desa Cihamerang merupakan salah satu dari enam desa yang ada di Kecamatan Kabandungan. Bagian utara Desa Cihamerang berbatasan langsung dengan Desa Cipeuteuy, dan di sebelah timur berbatasan dengan Sungai Citarik. Batas sebelah selatan dan timur Desa Cihamerang adalah wilayah hutan, baik milik perhutani maupun Taman Nasional Gunung Halimun Salak. Wilayah Desa Cihamerang memiliki bentuk topografi berbukit-bukit dan pegunungan yang membentang di gunung Salak dengan warna tanah merah dan derajat kesuburan lempungan. Ketinggian wilayah Desa Cihamerang mencapai 700-850 meter di bawah permukaan laut. Iklim Desa Cihamerang tergolong iklim basah, dimana hal tersebut dapat dilihat dari curah hujan rata-rata, yaitu $200 \mathrm{~mm}$ dan jumlah bulan hujan selama delapan bulan. Letaknya yang secara geografis berada di kawasan pegunungan membuat suhu harian di desa ini mencapai $20{ }^{\circ} \mathrm{C}$. Kondisi iklim demikian sangat cocok dengan corak hidup dan mata pencaharian masyarakat yang bertumpu pada sektor pertanian, khususnya pertanian tanaman pangan. Seiring dengan fenomena semakin meningkatnya pemanasan global terutama di wilayah pegunungan, seringkali hujan turun tidak menentu di wilayah Desa Cihamerang.

Jumlah masyarakat desa ini mencapai 6.715 jiwa yang terbagi ke dalam 1761 kepala keluarga (KK) dengan proporsi seimbang antara jumlah masyarakat perempuan dan laki-laki, yaitu sebanyak 3369 jiwa untuk laki-laki dan 3346 jiwa untuk perempuan. Data kemasyarakatan menunjukkan bahwa sebagian besar masyarakat yang sekolah hanya mampu mencapai tahap Sekolah Dasar (SD), kemudian kurang dari sepertujuhnya melanjutkan ke Sekolah Menegah Pertama (SMP), dan yang akhirnya melanjutkan ke SMA hanya setengah dari masyarakat yang melanjutkan pendidikan ke tingkat SMP, sedangkan sisanya tidak mengenyam pendidikan sama sekali. Kondisi tersebut juga disebabkan oleh keterbatasan sarana pendidikan yang ada di desa ini, dimana hanya ada empat Sekolah Dasar di wilayah Desa Cihamerang, dan untuk melanjutkan ke jenjang SMP atau SMA mereka harus menuju ibukota Kecamatan Kabandungan. Sebagian besar masyarakat bekerja di sektor pertanian, baik sebagai petani maupun hanya sebagai buruh tani, kemudian sebagian kecil masyarakat menggantungkan hidupnya dengan bekerja sebagai pedagang keliling, pengerajin, PNS, pembantu rumah tangga, dll. Sektor pertanian menjadi tumpuan penduduk Desa Cihamerang, yakni dengan komoditas tanaman unggulan di desa ini adalah padi, namun komoditas lain yang juga dikembangkan adalah jagung, ubi kayu, ubi jalar, tomat, mentimun, buncis, terong, cabai, dan sawi.

\section{Perusahaan Geothermal}


Perusahaan geothermal di wilayah Salak merupakan bagian dari Perusahaan Geothermal Indonesia, yang beroperasi di Kabupaten Sukabumi dan Kabupaten Bogor. Perusahaan ini mulai melakukan operasi panasbumi di kawasan area Gunung Salak, Kabupaten Bogor dan Kabupaten Sukabumi sejak tahun 1982. Perusahaan Geothermal mengelola energi panasbumi menjadi energi listrik. Energy Geothermal (energi panas bumi) adalah energi yang dihasilkan oleh tekanan panas bumi. Energi yang berasal dari kerak bumi ini dapat dimanfaatkan untuk menghasilkan listrik. Perusahaan Geothermal memiliki komitmen untuk membangun dan membuka hubungan positif dengan masyarakat setempat, khususnya masyarakat yang berada paling dekat dengan wilayah operasi. Kebijakan sosial telah diterapkan termasuk komitmen untuk menyediakan peluang di bidang pengembangan sosial, pendidikan, ekonomi, pelatihan, dan memperkerjakan warga setempat di sekitar perusahaan melalui penyelenggaraan Corporate Social Responsibility. Departemen PGPA inilah yang bertanggung jawab dalam program CSR yang dilakukan oleh Perusahaan Geothermal, diantaranya program Community Based Micro Finance (CBMF) melalui Koperasi Kartini di Kabandungan. Tujuan kerja dari Departemen PGPA adalah membangun image dan reputasi perusahaan, memiliki hubungan saling pengertian, suara yang sama, dan penerimaan dari stakeholder.

\section{Lembaga Keuangan Mikro Syariah (LKMS) Kartini}

Lembaga Keuangan Mikro Syariah (LKMS) Kartini merupakan Lembaga Keuangan Mikro (LKM) yang dibentuk sebagai salah satu aktualisasi penyelenggaraan Corporate Social Responsibility (CSR) oleh Perusahaan Geothermal dalam hal pengembangan ekonomi masyarakat di tingkat lokal. Kegiatan ini merupakan bagian dari rangkaian program community development (Pengembangan Masyarakat) Perusahaan Geothermal sebagai wujud dari program Corporate Social Responsibility (CSR) yang dalam hal ini disebut sebagai program Community Engagement. Lembaga ini berbadan hukum Koperasi no. 22/BH/XIII.15/V/2009 pada tanggal 22 Mei 2009. Kegiatan usaha Kartini bergerak dalam bidang Jasa Keuangan Syariah yang diperkenalkan kepada masyarakat dengan nama Lembaga Keuangan Mikro Syariah (LKMS). Kantor operasional saat ini beralamat di J1. Babakan Jayanegara Gunung Salak RT 08/04, Desa Kabandungan, Kecamatan Kabandungan, Kabupaten Sukabumi, Jawa Barat.

Visi dari Lembaga Keuangan Syariah Kartini adalah menjadi Lembaga Keuangan Syariah yang terbaik dan terdepan secara regional dalam membangun kekuatan ekonomi umat yang dapat meningkatkan kesejahteraan bersama secara adil dan merata sesuai dengan prinsipprinsip syariah serta menjadi mitra dan memberi solusi yang bermakna bagi kaum dhuafa, pengusaha mikro dan kecil secara berkelanjutan dengan berlandaskan pada prinsip-prinsip fathonah, amanah, shiddiq dan tabligh. Sedangkan misinya adalah meningkatkan akses permodalan bagi masyarakat kecil baik finansial maupun nonfinansial, membantu menciptakan lapangan kerja dan meningkatkan produktivitas masyarakat kecil demi kesejahteraan dan keadilan ekonomi, membantu mencari dan menciptakan pasar yang dapat menyerap hasil produksi masyarakat, menjadi Lembaga Keuangan Syariah yang tumbuh secara berkelanjutan seiring dengan pertumbuhan usaha nasabahnya, melaksanakan pendidikan dan pelatihan ekonomi syariah dalam rangka mendukung penguatan ekonomi syariah dalam praktik, baik melalui institusi keuangan maupun kegiatan bisnis dan usaha riil. Rapat pembentukan LKMS Kartini diselenggarakan pada pertengahan tahun 2008 dengan kerjasama antara Perusahaan Geothermal dan PNM sebagai penyelenggara. Setelah itu kedua pihak melakukan sosialisasi kepada masyarakat yang berminat dalam pendirian LKMS ini. Selanjutnya terbentuklah kelompok pendiri yang ditargetkan dapat mengumpulkan modal awal dari masyarakat untuk proses awal pendirian koperasi. Dalam perjalannya, LKMS Kartini dikelola oleh masyarakat yang memiliki inisiasi awal dengan dibantu oleh beberapa staff yang direkrut langsung dari masyarakat, mewakili masing-masing desa yang memiliki keanggotaan di LKMS Kartini.

\section{HASIL PENELITIAN}

\section{Tingkat Partisipasi}

\section{Tingkat Partisipasi Anggota Kelompok Simpan Pinjam dalam Penyelenggaraan Program}

Tingkat partisipasi anggota kelompok simpan pinjam LKMS Kartini dalam penyelenggaraan program pemberdayaan ekonomi lokal melalui pembentukan Lembaga Keuangan Mikro Syariah Kartini di Kecamatan Kabandungan, khususnya Desa Cihamerang, didasarkan pada tahapan partisipasi menurut Uphoff (1979). Pada praktek penyelenggaraan program, terdapat berbagai jenjang partisipasi dari anggota kelompok simpan pinjam LKMS Kartini, dimana seluruh jenjang ini ditentukan oleh seberapa jauh masyarakat berpartisipasi/terlibat pada seluruh tahapan proses penyelenggaraan. Pengukuran tingkat partisipasi dilakukan berdasarkan keterlibatan anggota kelompok simpan pinjam terhadap kegiatan dalam tahapan penyelenggaraan program yang dilaksanakan, baik pada tahap perencanaan, tahap pelaksanaan, tahap evaluasi, maupun tahap pelaporan. Pada setiap tahapan penyelenggaraan, dilihat sejauhmana keterlibatan anggota kelompok simpan pinjam,termasuk frekuensi kehadiran, tingkat keaktifan, tingkat pemahaman, dan juga keterlibatan dalam pengambilan keputusan. Keempat kategori responden dalam penelitian memiliki tingkatan partisipasi yang berbeda-beda. Hal tersebut dapat dilihat dari pie chart berikut: 


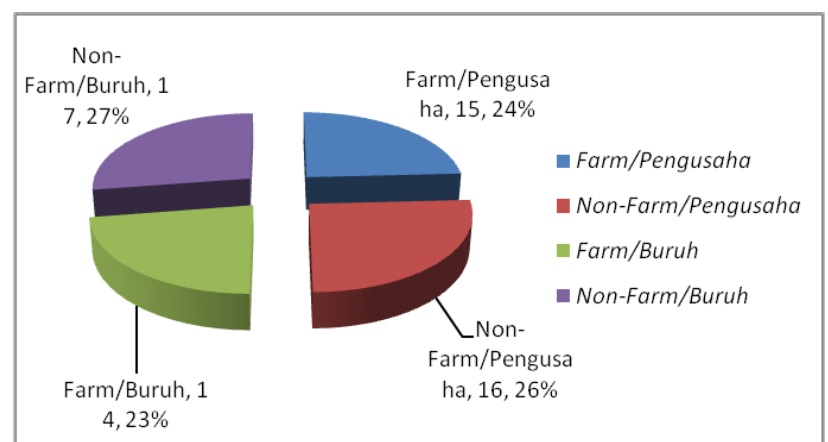

Gambar 2. Persentase Tingkat Partisipasi Anggota Kelompok Simpan Pinjam LKMS Kartini dalam Program Menurut Kategori Sosial

Berdasarkan pie chart di atas, dapat dilihat bahwasanya dari 30 orang responden penelitian, kategori sosial 4 yaitu kategori sosial non-farm/buruh memiliki keterlibatan paling tinggi, sedangkan kategori sosial 3 yaitu kategori sosial farm/buruh memiliki keterlibatan yang paling rendah dalam partisipasi terhadap program dari keseluruhan 30 responden. Keempat kategori sosial tersebut memiliki senjang nilai yang masing-masing tidak terlalu jauh. Berikut adalah tabel yang menggambarkan skor tingkat partisipasi dan skor kekuatan modal sosial 30 orang responden dari anggota kelompok simpan pinjam LKMS Kartini:

Tabel 2. Tingkat Partisipasi dan Kekuatan Modal Sosial Anggota Kelompok Simpan Pinjam LKMS Kartini Menurut Konsep Uphoff

\begin{tabular}{|c|c|c|c|c|c|c|c|}
\hline \multirow[b]{2}{*}{ No } & \multirow[b]{2}{*}{\begin{tabular}{|c} 
Kategori \\
Tinghat \\
Partispasi \\
Anggota \\
Kelompok \\
Simpan \\
Pimjam
\end{tabular}} & \multirow[b]{2}{*}{$\begin{array}{c}\text { Jumlah } \\
\text { Anggota } \\
\text { Keloumpok } \\
\text { Simpan } \\
\text { Pimjam }\end{array}$} & \multirow[b]{2}{*}{$\begin{array}{c}\text { Persentase } \\
\text { Jumlah } \\
\text { Anggotata } \\
\text { Relompol } \\
\text { Simpan } \\
\text { Pimjam }\end{array}$} & \multicolumn{4}{|c|}{ Skor Rata-Rata Kexuatan Modal Sosial Anggota Kelompol Simpan Pinjam } \\
\hline & & & & $\begin{array}{l}\text { Skor Rata-Rata } \\
\text { Tinghat } \\
\text { Kepercayaan } \\
\text { Anggota } \\
\text { Kelompol }\end{array}$ & $\begin{array}{c}\text { Skor Rata-rata } \\
\text { Keluatan } \\
\text { Jejaring } \\
\text { Anggota } \\
\text { Kelompol }\end{array}$ & $\begin{array}{c}\text { Skor Rata-rata } \\
\text { Keluatatan } \\
\text { Kejasama } \\
\text { Angegota } \\
\text { Kelompol }\end{array}$ & $\begin{array}{l}\text { Skor Total Rata- } \\
\text { rata Kekuatan } \\
\text { Modal Sosial } \\
\text { Anggota } \\
\text { Kelompok Smpan } \\
\text { Pinjam } \\
\end{array}$ \\
\hline 1 & Tinggi & 1 & $3 \%$ & 4,6 & 4,1 & 4,4 & 4,4 \\
\hline 2 & Sedang & 18 & $60 \%$ & 4,1 & 3,4 & 3,4 & 3,6 \\
\hline 3 & Rendah & 11 & $37 \%$ & 4 & 3,3 & 3,3 & 3,5 \\
\hline
\end{tabular}

Sedangkan untuk tingkat partisipasi dan taraf hidup digambarkan melalui tabel di bawah ini :

Tabel 3. Tingkat Partisipasi dan Taraf Hidup Anggota Kelompok Simpan Pinjam LKMS Kartini Menurut Konsep Uphoff

\begin{tabular}{|c|c|c|c|c|c|c|c|}
\hline \multirow[b]{2}{*}{.10} & \multirow[b]{2}{*}{$\begin{array}{l}\text { Kategon } \\
\text { Tingkat } \\
\text { Patisippad } \\
\text { Anggota } \\
\text { Kelonpok } \\
\text { Simpan } \\
\text { Pinjam }\end{array}$} & \multirow[b]{2}{*}{$\begin{array}{c}\text { Jumlah } \\
\text { Anggota } \\
\text { Kelompok } \\
\text { Simpan } \\
\text { Pinjam }\end{array}$} & \multirow[b]{2}{*}{$\begin{array}{c}\text { Persentase } \\
\text { Jumlah } \\
\text { Anggota } \\
\text { Kelompok } \\
\text { Simpan } \\
\text { Pinjam }\end{array}$} & \multicolumn{4}{|c|}{ Rata-Rata Taraf Hidup Angogota Kelompok Simpan Pinjam } \\
\hline & & & & $\begin{array}{l}\text { Skor Rata- } \\
\text { Rata Taraf } \\
\text { Hidup } \\
\text { Anggota } \\
\text { Kelompok } \\
\text { Simpan } \\
\text { Pinjam } \\
\end{array}$ & $\begin{array}{c}\text { Rata.rata } \\
\text { Tingkat } \\
\text { Pendapatan } \\
\text { Angogota } \\
\text { Kelompok } \\
\text { Simpan Pinjam }\end{array}$ & $\begin{array}{l}\text { Ratarata Tingkat } \\
\text { Pengeluaran } \\
\text { Angogota } \\
\text { Kelompok } \\
\text { Simpan Pinjam }\end{array}$ & $\begin{array}{l}\text { Total Rata-rata } \\
\text { Tingkat Tabungan } \\
\text { Anggota } \\
\text { Kelompok } \\
\text { Simpan Pinjam }\end{array}$ \\
\hline & Timgg & 1 & $3,33 \%$ & 4,6 & 9000000 & 1500000 & 600000 \\
\hline & Sedang & 18 & $60 \%$ & 4,2 & 1865000 & 1008000 & 310800 \\
\hline & Rendah & 11 & $36,67 \%$ & 4 & 1573600 & 1063600 & 45500 \\
\hline
\end{tabular}

Tabel 2 dan Tabel 3 menunjukkan adanya gradasi tingkat partisipasi dalam penyelenggaraan program dari keseluruhan responden yang merupakan anggota kelompok simpan pinjam LKMS Kartini. Tingkat partisipasi responden dalam penyelenggaraan program terklasifikasi berdasarkan kategori tinggi, rendah, dan sedang yang mengacu pada konsep partisipasi menurut Uphoff (1979), yang mana partisipasi diukur menurut tahapan penyelenggaraan kegiatan, meliputi perencanaan, pelaksanaan, evaluasi, dan sebagai tambahan adalah tahapan pelaporan. Begitu pula dengan skor modal sosial dari masing-masing indikator dalam variabel kekuatan modal sosial dan taraf hidup. Secara umum, tingkatan partisipasi dari 30 responden yang terbagi menjadi tiga kategori, searah juga dengan tingkatan skor modal sosial dan taraf hidup responden. Itu artinya peningkatan partisipasi anggota kelompok simpan pinjam diiringi peningkatan kekuatan modal sosial dan taraf hidup anggota. Namun, dapat dilihat bahwasanya aspek tingkat pengeluaran tidak secara penuh berhubungan dengan sejauhmana tingkat partisipasi anggota kelompok simpan pinjam Dapat dilihat adanya gradasi yang beracak terhadap tingkatan partisipasi. Berikut adalah pie chart yang menggambarkan persentase anggota kelompok simpan pinjam dari 30 orang responden berdasarkan tingkatannya:

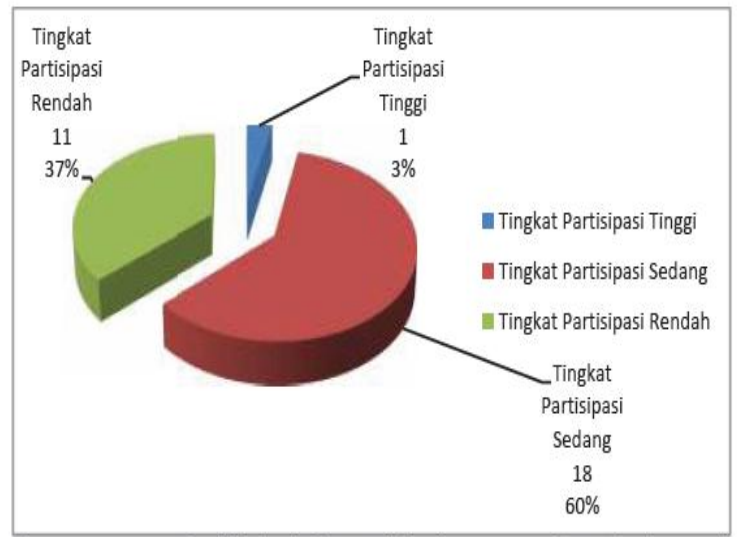

Gambar 3. Persentase Klasifikasi Tingkat Partisipasi Anggota Kelompok Simpan Pinjam LKMS Kartini

Gambar 3 memaparkan persentase klasifikasi tingkat partisipasi anggota berdasarkan derajat tinggi, rendah, maupun sedang. Pengklasifikasian tersebut didasarkan pada skor yang diperoleh dari hasil kuesioner dan hasil menunjukkan bahwasanya sebagian besar anggota berada pada level tingkat partisipasi sedang, yakni sejumlah 17 responden dari 30 responden anggota kelompok. Sedangkan untuk Tingkat partisipasi rendah berjumlah 12 responden dari 30 responden dan dengan jumlah terkecil adalah anggota dengan tingkat partisipasi tertinggi yang hanya berjumlah satu orang. Meskipun tingkat partisipasi anggota kelompok LKMS Kartini di Desa Cihamerang bergradasi, namun kecenderungannya partisipasi anggota LKMS belum dapat dikategorikan memiliki tingkatan yang tinggi karena jumlah tertinggi masih berada pada tingkat sedang dan rendah.

Sebagai pembanding dalam mengidentifikasi tingkat partisipasi anggota kelompok simpan pinjam LKMS Kartini, dilakukan identifikasi dan analisis mengenai tingkat partisipasi anggota dengan konsep Arnstein 
(1969), yang manatingkatan partisipasi terbagi menjadi delapan tipe tahapan berdasarkan hubungan kekuasaan diantara stakeholder. Kedelapan tipe tingkatan tersebut adalah tipe manipulasi, tipe terapi, tipe pemberitahuan, tipe konsultasi, tipe penentraman, tipe kemitraan, tipe pendelegasian kekuasaan, tipe kontrol masyarakat. Berikut adalah tabel yang menggambarkan tingkat partisipasi anggota kelompok simpan pinjam dan juga kekuatan modal sosial dari anggota tersebut berdasarkan tangga partisipasi Arnstein:

Tabel 4. Tingkat Partisipasi dan Kekuatan Modal Sosial Anggota Kelompok Simpan Pinjam LKMS Kartini Menurut Konsep Arnstein

\begin{tabular}{|c|c|c|c|c|c|c|c|}
\hline \multirow[b]{2}{*}{ No } & \multirow[b]{2}{*}{$\begin{array}{l}\text { Kategori Tingkat } \\
\text { Partisipasi } \\
\text { Anggota } \\
\text { Kelompok } \\
\text { Simpan Pinjam }\end{array}$} & \multirow[b]{2}{*}{$\begin{array}{c}\text { Jumlah } \\
\text { Anggota } \\
\text { Kelompok } \\
\text { Simpan } \\
\text { Pinjam }\end{array}$} & \multirow[b]{2}{*}{$\begin{array}{c}\text { Persentase } \\
\text { Jumlah } \\
\text { Anggota } \\
\text { Kelompok } \\
\text { Simpan } \\
\text { Pinjam }\end{array}$} & \multicolumn{4}{|c|}{ Skor Rata-Rata Kekuatan Modal Sosial Anggota Kelompok Simpan Pinjam } \\
\hline & & & & $\begin{array}{c}\text { Skor Rata-Rata } \\
\text { Tingkat } \\
\text { Kepercayaan } \\
\text { Anggota } \\
\text { Kelompok } \\
\text { Simpan Pinjam }\end{array}$ & $\begin{array}{c}\text { Skor Rata-rata } \\
\text { Keluatan } \\
\text { Jejaring } \\
\text { Anggota } \\
\text { Kelompok } \\
\text { Simpan Pinjam }\end{array}$ & $\begin{array}{l}\text { Skor Rata-rata } \\
\text { Keluatan } \\
\text { Kerjasama } \\
\text { Anggota } \\
\text { Kelompok } \\
\text { Simpan Pinjam }\end{array}$ & $\begin{array}{c}\text { Skor Total Rata- } \\
\text { rata Kekuatan } \\
\text { Modal Sosial } \\
\text { Anggota } \\
\text { Kelompok } \\
\text { Simpan Pinjam }\end{array}$ \\
\hline 1 & \begin{tabular}{|l|} 
Tipe \\
Penentraman \\
\end{tabular} & 4 & $13 \%$ & 4,4 & 3,3 & 3,7 & 3,8 \\
\hline 2 & Tipe Konsultasi & 13 & $43 \%$ & 4 & 3,5 & 3,2 & 3,6 \\
\hline 3 & $\begin{array}{l}\text { Tipe } \\
\text { Pemberitahuan }\end{array}$ & 13 & $44 \%$ & 4 & 3,3 & 3,4 & 3,5 \\
\hline
\end{tabular}

Tabel 5. Tingkat Partisipasi dan Taraf Hidup Anggota Kelompok Simpan Pinjam LKMS Kartini Menurut Konsep Arnstein

\begin{tabular}{|c|c|c|c|c|c|c|c|}
\hline \multirow[b]{2}{*}{ NO } & \multirow[b]{2}{*}{$\begin{array}{l}\text { Kategori Tingkat } \\
\text { Partisipasi } \\
\text { Anggota } \\
\text { Kelompok } \\
\text { Simpan Pinjam }\end{array}$} & \multirow[b]{2}{*}{$\begin{array}{l}\text { Jumlah } \\
\text { Anggota } \\
\text { Kelompok } \\
\text { Simpan } \\
\text { Pinjam }\end{array}$} & \multirow[b]{2}{*}{$\begin{array}{l}\text { Persentase } \\
\text { Anggota } \\
\text { Kelompok } \\
\text { Simpan } \\
\text { Pinjam }\end{array}$} & \multicolumn{4}{|c|}{ Rata-Rata Taraf Hidup Anggota Kelompok Simpan Pinjam } \\
\hline & & & & $\begin{array}{l}\text { Skor Rata-Rata } \\
\text { Taraf Hidup } \\
\text { Anggota } \\
\text { Kelompok } \\
\text { Simpan Pinjam }\end{array}$ & $\begin{array}{c}\text { Rata-rata } \\
\text { Tingkat } \\
\text { Pendapatan } \\
\text { Anggota } \\
\text { Kelompok } \\
\text { Simpan PInjam }\end{array}$ & $\begin{array}{c}\text { Rata-rata } \\
\text { Tingkat } \\
\text { Pengeluaran } \\
\text { Anggota } \\
\text { Kelompok } \\
\text { Simpan Pinjam }\end{array}$ & $\begin{array}{c}\text { Total } \\
\text { Rata-rata Tingkat } \\
\text { Tabungan } \\
\text { Anggota } \\
\text { Relompok Simpan } \\
\text { Pimjam }\end{array}$ \\
\hline 1 & $\begin{array}{l}\text { Tipe } \\
\text { Penentraman }\end{array}$ & 4 & $13 \%$ & 4,4 & 5180000 & 1225000 & 1460000 \\
\hline 2 & Tipe Konsultasi & 13 & $43 \%$ & 4 & 1705800 & 1004100 & 23750 \\
\hline 3 & $\begin{array}{l}\text { Tipe } \\
\text { Pemberitahuan }\end{array}$ & 13 & $44 \%$ & 4 & 1335000 & 1025500 & 40700 \\
\hline
\end{tabular}

Tabel 4 dan Tabel 5 menggambarkan skor dan tingkatan partisipasi anggota kelompok simpan pinjam LKMS Kartini mengacu pada konsep partisipasi menurut Arnstein (1969), dimana dalam penelitian ini didapatkan pengkategorian partisipasi anggota ke dalam tiga tingkatan pada hubungan kekuasaan tokenism, yakni berkisar diantara tipe pemberitahuan, tipe konsultasi, dan tipe penentraman. Gradasi tingkat partisipasi anggota kelompok, dalam hal ini diwakili oleh 30 responden, berkaitan dengan kondisi kekuatan modal sosial dan taraf hidup anggota kelompok. Secara umum, tingkatan partisipasi anggota kelompok simpan pinjam yang dikategorikan menurut konsep Arnstein (1969) sejalan dengan tingkatan kekuatan modal sosial dan taraf hidup anggota kelompok simpan pinjam.

Berikut adalah gambar pie chart mengenai persentase tingkat partisipasi anggota kelompok simpan pinjam LKMS Kartini berdasarkan tipe-tipe partisipasi Arnstein (1969):

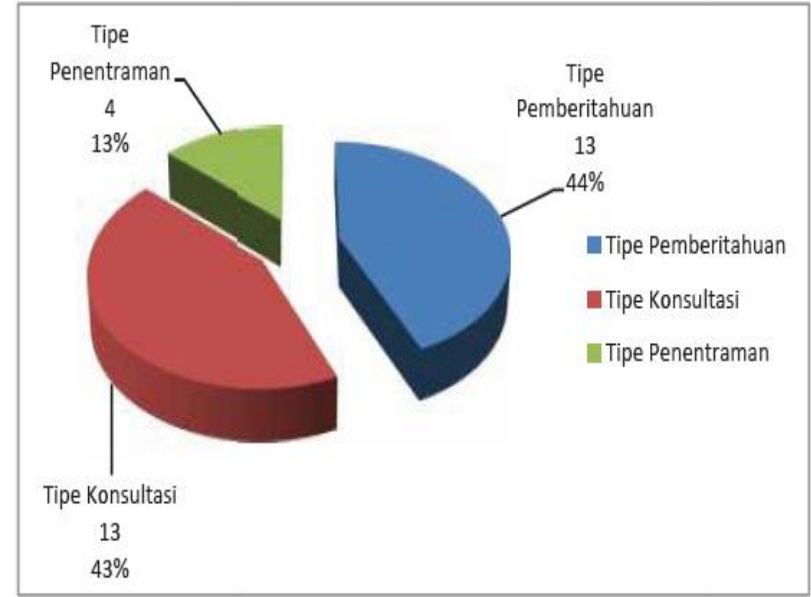

Gambar 4. Persentase Tipe Partisipasi Anggota Kelompok Simpan Pinjam Menurut Tangga Partisipasi Arnstein

Gambar di atas menjelaskan mengenai persentase tingkat partisipasi anggota berdasarkan tingkatan partisipasi Arnstein (1969), yang mana dapat dilihat bahwasanya sebagian besar anggota kelompok simpan pinjam tergolong berpartisipasi pada tipe pemberitahuan dan kosultasi. Itu artinya, dalam penyelenggaraan program CSR tersebut, anggota kelompok simpan pinjam masih berposisi sebagai objek dari program pemberdayaan. Anggota kelompok simpan pinjam belum sepenuhnya memiliki kekebasan untuk menyampaikan saran dan aspirasi, terlebih dalam pengambilan keputusan. Saran dan pendapat cenderung dapat disampaikan, namun belum tentu dipenuh dan dilaksanakan. Di samping itu, pada hubungan kekuasaan tokenism ini, anggota kelompok simpan pinjam masin berada di bawah kontrol dari pihak yang powerfull.

\section{Tingkat Partisipasi Stakeholder (Pemangku Kepentingan) dalam Penyelenggaraan Program}

Lembaga Keuangan Mikro Syariah (LKMS) Kartini merupakan LKM yang mendapatkan dari Perusahaan Geothermal untuk melakukan pengembangan ekonomi masyarakat di tingkat lokal, yakni melalui program Community Based Micro Finance (CBMF). Penyelenggaraan LKMS Kartini ini merupakan wujud dari pelaksanaan program community development Perusahaan Geothermal sebagai bagian dari corporate social responsibility implementation. Dalam penyelenggaraan LKMS Kartini tersebut, melibatkan berbagai pihak (stakeholder), yakni pemerintah desa dan kecamatan, dinas koperasi, mitra perusahaan, dan masyarakat. Terkait dengan bagaimana dan sejauhmana keterlibatan stakeholder-stakeholder dalam penyelenggaran LKMS Kartini dapat dilihat melalui tabel berikut: 
Tabel 6. Keterlibatan Stakeholder-stakeholder dalam Penyelenggaraan Program

\begin{tabular}{|c|c|}
\hline $\begin{array}{c}\text { Tahapan } \\
\text { Penyelenggaraan }\end{array}$ & $\begin{array}{c}\text { Stakeholder yang Terlibat dalam Masing-masing Tahapan Penyelenggaraannya } \\
\text { beserta Bentuk Keterlibatannya }\end{array}$ \\
\hline Tahap Perencanaan & $\begin{array}{l}\text { - Pengurus Koperasi: Ide untuk menyelenggarakan program pemberdayaan } \\
\text { ekonomi yang berkelanjutan (sustainable) } \\
\text { - Perusahaan dan Mitra: Menyusun perencanaan keseluruhan baik yang } \\
\text { bersifat teknis maupun non-teknis } \\
\text { - Pemerintah Desa/Kecamatan: Pemberian informasi dan perekruitan } \\
\text { pengurus koperasi } \\
\text { - Dinas Koperasi: melakukan audit kelayakan awal dan juga mengeluarkan } \\
\text { izin pendirian koperasi untuk LKMS Kartini }\end{array}$ \\
\hline Tahap Pelaksanaan & $\begin{array}{l}\text { - Pengurus Koperasi dan Anggota Kelompok: Baik sebagai anggota } \\
\text { maupun pengurus, pengurus dalam hal ini terlibat dalam kegiatan } \\
\text { langsung koperasi serta mengikuti pelatihan-pelatihan untuk menguatkan } \\
\text { kapasitas, sedangkan anggota dalam hal ini mengikuti program simpan } \\
\text { pinjam yang setiap minggu diselenggarakan pertemuan mingguan. } \\
\text { - Mitra Perusahaan: melakukan pendampingan terhadap seluruh aktivitas } \\
\text { koperasi, meliputi misalnya Accounting, Standart Operation } \\
\text { Procedure(SOP), Madani Micro Banking System (MMS), dil. } \\
\text { - Perusahaan: Hanya sekedar mengontrol kegiatan koperasi, tanpa terlibat } \\
\text { langsung di dalamnya } \\
\text { - Pemerintah Desa/Kecamatan: memiliki fungsi perizinan, namun dalam } \\
\text { pelaksanaannya, tidak terlibat langsung }\end{array}$ \\
\hline Tahap Evaluasi & $\begin{array}{l}\text { - Anggota tidak terlibat langsung, dalam hal ini hanya pengurus koperasi } \\
\text { yang terlibat dalam tahap evaluasi kegiatan koperasi. } \\
\text { - Mitra Perusahaan: bersama-sama pengurus koperasi mengevaluasi } \\
\text { sejauhmana pencapaian koperasi dalam hal kenaikan pembiayaan, } \\
\text { penambahan anggota, pembiayaan macet, peningkatan pendapatan, } \\
\text { kinerja pelaksana } \\
\text { - Pemerintah Desa/Kecamatan: hanya sebatas mengetahui, namun tidak } \\
\text { dilibatkan dalam evaluasi (dianggap terlalu rumit, hanya berorientasi } \\
\text { pada uang) } \\
\text { - Perusahaan: menerima hasil evaluasi dari mitra, kemudian bersama-sama } \\
\text { dengan mitra, membahas permasalahan tersebut sekaligus mencari solusi } \\
\text { yang tepat }\end{array}$ \\
\hline Tahap Pelaporan & $\begin{array}{l}\text { - Masyarakat: Dalam hal ini hanya pengurus koperasi saja yang terlibat } \\
\text { untuk membuat pelaporan } \\
\text { - Mitra Perusahaan: menerima pelaporan dari pengurus koperasi } \\
\text { - Perusahaan: menerima pelaporan dari mitra perusahaan sebagai } \\
\text { pertimbangan untuk langkah selanjutnya } \\
\text { - Pemerintah Desa/Kecamatan: tidak dilibatkan sama sekali dalam tahap } \\
\text { pelaporan }\end{array}$ \\
\hline
\end{tabular}

Community Development (Pengembangan Masyarakat) sebagai salah satu dari tujuh isu CSR merupakan sarana aktualisasi CSR yang paling baik jika dibandingkan dengan implementasi yang hanya berupa charity, philantrophy, atau dimensi-dimensi CSR yang lain, karena dalam pelaksanaan community development terdapat prinsip-prinsip kolaborasi kepentingan bersama antara perusahaan dengan komunitas, adanya partisipasi, produktivitas, keberlanjutan, dan mampu meningkatkan perasaan solidaritas. Stakeholders, yang jamak diterjemahkan dengan pemangku kepentingan adalah pihak atau kelompok yang berkepentingan, baik langsung maupun tidak langsung terhadap eksistensi atau aktivitas perusahaan, dan karenanya kelompok-kelompok tersebut mempengaruhi dan atau dipengaruhi oleh perusahaan (Saidi, 2004). Pemberdayaan memiliki dua elemen pokok, yakni kemandirian dan partisipasi. Partisipasi adalah proses aktif, inisiatif diambil oleh warga komunitas sendiri, dibimbing oleh cara berfikir mereka sendiri, dengan menggunakan sarana dan proses (lembaga dan mekanisme) dimana mereka dapat menegaskan kontrol secara efektif. Menurut Nasdian (2006), pemberdayaan merupakan jalan atau sarana menuju partisipasi. Sebelum mencapai tahap tersebut, tentu saja dibutuhkan upaya-upaya pemberdayaan masyarakat. Oleh karena itu, pemberdayaan masyarakat tidak akan berhasil tanpa partisipasi dari seluruh pemangku kepentingan yang terlibat.
Perusahaan Geothermal dan Mitra Perusahaan (PNM), kedua stakeholder tersebut terlibat pada setiap tahapan penyelenggaraan program. Dalam hal ini, perusahaan geothermal adalah pihak yang pertama kali memfasilitasi ide dari masyarakat yang saat ini menjadi pengurus koperasi untuk membentuk sebuah lembaga keuangan mikro sebagai pendukung dari keberadaan usaha-usaha kecil menengah di tingkat masyarakat lokal, sedangkan mitra perusahaan dalam hal ini berpartisipasi sebagai fasilitator yang mendampingi koperasi pada setiap tahapan penyelenggaraan program. Bentuk partisipasi kedua pihak tersebut memang cenderung berbeda, perusahaan geothermal lebih berperan dalam bidang manajerial program, sedangkan mitra perusahaan lebih ke hal-hal teknis pada seluruh tahapan penyelenggaraan. Tipe kemitraan dalam tingkatan partisipasi kedua pemangku kepentingan tersebut menggambarkan bagaimana tingkatan kekuasaan yang mereka miliki. Kedua belah pihak stakeholder memiliki kerjasama yang saling menguntungkan satu sama lain, tapi keduanya memiliki kontrol melalui keterlibatannya tersebut. Masyarakat dalam hal ini yang berposisi sebagai pengurus koperasi juga memiliki tipe partisipasi kemitraan. Ide pendirian koperasi ini berasal dari kategori masyarakat tersebut, namun dalam perencanaan program, para pengurus koperasi ini tidak dilibatkan dalam perancangan program. Para pengurus tersebut, mengikuti tahapan yang telah dipersiapkan oleh para konseptor, baik dari Perusahaan Geothermal maupun mitra perusahaan. Jadi secara umum, ketiga stakeholder tersebut berpartisipasi pada keseluruhan tahapan penyelenggaraan sesuai dengan konsep partisipasi menurut Uphoff (1979), meskipun dengan jenis keterlibatan yang berbeda-beda. Pengurus Koperasi cenderung berpartisipasi penuh pada tahapan pelaksanaan hingga pelaporan, sedangkan pada tahap perencanaan tidak memegang kendali untuk merancang perihal teknis dan non-teknis program, sedangkan untuk Perusahaan Geothermal dan mitra terlibat dalam setiap tahapan.

Anggota kelompok simpan pinjam LKMS Kartini dan Dinas Koperasi merupakan dua pihak stakeholder yang memiliki tipe partisipasi dalam hubungan kekuasaan yang bersifat tokenism. Tipe partisipasi stakeholderstakeholder tersebut berada pada tingkatan pemberitahuan, konsultasi, hingga penentraman, dimana seluruh stakeholder terkait diberikan pendampingan dan konsultasi oleh semua pihak (pemerintah dan perusahaan) sehingga pandangan-pandangan diperhitungkan dan tetap dilibatkan dalam menentukan keputusan. Dinas Koperasi dalam hal ini memiliki wewenang untuk melakukan audit pada kelayakan LKMS Kartini untuk selanjutnya diberi izin pendirian koperasi sehingga harus mengimplementasikan kaidah-kaidah pada Badan Hukum Koperasi. Oleh karena itu, jika dikaitkan dengan konsep partisipasi menurut Uphoff (1979), Dinas Koperasi hanya terlibat pada tingkat perencanaan saja. Masyarakat yang tergolong sebagai anggota koperasi maupun anggota kelompok cenderung hanya terlibat pada tahapan pelaksanaan. Sebagian besar masyarakat memiliki intensitas keterlibatan yang tinggi, khususnya pada pertemuan/kumpulan mingguan kelompok. Beberapa anggota kelompok simpan pinjam memiliki kemampuan 
dalam menyampaikan pendapat dan mengambil keputusan, namun yang menjadi masalah adalah akses mereka cenderung terbatas. Anggota kelompok berposisi lebih kepada penerima program yang selanjutnya diarahkan untuk bisa mengembangkan usaha pribadi secara mandiri, bukan ditekankan pada partisipasi dalam penyelenggaraan LKMS.

Stakeholder yang terakhir adalah pemerintah Desa Cihamerang dan pemerintah Kecamatan Kabandungan. Pemerintah lokal dalam hal ini hanya terlibat pada evaluasi, itu pun dengan derajat keterlibatan yang sangat rendah. Kedua stakeholder tersebut memiliki posisi dan derajat keterlibatan yang sama dengan tipe partisipasi terapi, dimana pada tingkatan tersebut stakeholder tidak terlibat secara langsung dalam program ini. Dapat dilihat dari tabel di atas, pihak pemerintah desa dan kecamatan hanya berposisi sebagai pemberi izin bagi penyelenggaraan program ini karena dalam pelaksanaannya staff LKMS Kartini harus secara intensif terjun langsung ke lapangan, sehingga memerlukan dukungan dari pihak aparat desa maupun kecamatan dalam hal pendekatan kepada masyarakat calon anggota kelompok simpan pinjam. Selebihnya, aparat desa dan kecamatan hanya dilibatkan ketika ada event-event tertentu sebagai tamu undangan, serta memberikan saran dari perkembangan LKMS Kartini, namun dalam hal ini mereka tidak terlibat dalam penyelenggaraan baik pada tahapan perencanaan, pelaksanaan, bahkan pelaporan.

\section{Dampak Sosial dan Ekonomi dari Penyelenggaraan Program}

Perubahan yang dirasakan dan diperoleh oleh anggota kelompok simpan pinjam setelah terlibat dalam implementasi program CSR dengan mengacu pada variabel-variabel kemiskinan menurut BPS (2005) dalam Rahman (2009) dan indikator BPS dalam SUSENAS (2003). Adapun variabel-variabel yang digunakan untuk mengukur dampak ekonomi yang digunakan, diantaranya adalah variabel tingkat pendapatan, tingkat pengeluaran, tingkat tabungan, dan tingkat taraf hidup yang mencakup jenis lantai bangunan terluas tempat tinggal, jenis dinding rumah terluas, fasilitas tempat buang air besar/wc, sumber penerangan, sumber air minum, bahan bakar untuk memasak, dan alat transportasi yang dimiliki. Data mengenai dampak ekonomi penyelenggaraan program diperoleh dengan mencari selisih atau delta dari pendapatan anggota kelompok simpan pinjam dan nonanggota kelompok simpan pinjam LKMS Kartini pada setiap kategori sosial. Variabel pertama yang dilihat untuk mengukur dampak ekonomi adalah taraf hidup rumah tangga anggota kelompok simpan pinjam. Berikut adalah tabel yang menunjukkan bagaimana dampak penyelenggaraan program pemberdayaan ekonomi lokal terhadap taraf hidup rumah tangga anggota kelompok simpan pinjam LKMS Kartini:
Tabel 7. Skor Rata-rata Taraf Hidup Menurut Kategori Sosial

\begin{tabular}{|c|c|c|c|c|}
\hline \multirow[b]{2}{*}{ No } & \multirow[b]{2}{*}{ Kategoni Sosial } & \multicolumn{2}{|c|}{$\begin{array}{c}\text { Skor Rata-rata Taraf Hidup Menunut } \\
\text { Kategoni Sosial } \\
\end{array}$} & \multirow[b]{2}{*}{$A \cdot B$} \\
\hline & & $\begin{array}{c}\text { Anggota Kelompok } \\
\text { Simpan Pinjam } \\
\text { (A) }\end{array}$ & $\begin{array}{l}\text { Non-Anggota } \\
\text { Kelompok Simpan } \\
\text { Pinjam } \\
\text { (B) }\end{array}$ & \\
\hline 1 & Farm Pengusaha & 21 & 22 & .1 \\
\hline 2 & Non-Farm Pengusaha & 20.2 & 18 & 2.2 \\
\hline 3 & Farm Bunh & 15 & 16.4 & $-1,4$ \\
\hline 4 & Non-Farm Bunh & 20.9 & 18 & 2.9 \\
\hline
\end{tabular}

Berdasarkan hasil perhitungan tersebut, dapat diketahui bahwa tidak semua kategori sosial dari sejumlah 30 orang responden penelitian memperoleh dampak taraf hidup positif. Kategori sosial non-farm/pengusaha dan nonfarm/buruh memiliki dampak positif dalam taraf hidup, sedangkan dampak taraf hidup negatif dapat dilihat pada kategori sosial farm/pengusaha dan farm/buruh. Itu artinya, penyelenggaraan kegiatan pemberdayaan ekonomi melalui pembiayaan kelompok simpan pinjam belum tentu mementukan peningkatan taraf hidup anggota kelompok simpan pinjam.Untuk variabel tingkat pendapatan anggota kelompok simpan pinjam dapat dilihat melalui tabel berikut:

Tabel 8. Skor Rata-rata Pendapatan (Rp/Bulan) Menurut Kategori Sosial

\begin{tabular}{|c|c|c|c|c|}
\hline \multirow[b]{2}{*}{ No } & \multirow[b]{2}{*}{ Kategori Sosial } & \multicolumn{2}{|c|}{$\begin{array}{c}\text { Skor Rata-atata Pendappatan (Rpp Bulan) } \\
\text { Menurut Kategori Sosial }\end{array}$} & \multirow[b]{2}{*}{$A-B$} \\
\hline & & $\begin{array}{l}\text { Anggota Kelompok } \\
\text { Simpan Pinjam } \\
\text { (A) }\end{array}$ & $\begin{array}{c}\text { Non-Anggota } \\
\text { Kelompok Simpan } \\
\text { Pinjam } \\
\text { (B) }\end{array}$ & \\
\hline 1 & Farm/Pengusaha & 2170000 & 5108300 & .2938300 \\
\hline 2 & Non-Farm Pengusaha & 2990000 & 3450000 & -460000 \\
\hline 3 & FarmBundh & 793300 & 420000 & 373300 \\
\hline 4 & Non-FarmBunh & 1594000 & 1181700 & 412300 \\
\hline
\end{tabular}

Tabel di atas menunjukkan bahwasanya tidak semua kategori sosial dari 30 orang responden memperoleh dampak positif dalam tingkat pendapatan terhadap penyelenggaraan LKMS Kartini, dapat dilihat bahwa keterlibatan dalam program ini tidak memberikan dampak bagi pendapatan anggota kelompok dari kategori sosial farm/pengusaha dan non-farm/pengusaha, sedangkan anggota kelompok dari kategori sosial farm/buruh dan non-farm/buruh memperoleh dampak bagi pendapatannya. Hal tersebut dapat dilihat dari nilai delta yang positif pada pendapatan. Itu artinya keterlibatannya dalam penyelenggaraan program ini dimungkinkan membawa dampak bagi perolehan pendapatan rumah tangga per bulan.

Melihat aspek dampak pada tingkat pendapatan, perlu disesuaikan juga dengan bagaimana tingkat pengeluaran rumah tangga anggota kelompok simpan pinjam LKMS Kartini. Berikut adalah tabel yang menggambarkan bagaimana dampak terhadap tingkat pengeluaran rumah tangga anggota kelompok simpan pinjam LKMS Kartini:

62 Rosyida, Isma. et. al. Partisipasi Masyarakat dan Stakeholder dalam Penyelenggaraan Program Corporate Social Responsibility (CSR) dan Dampaknya terhadap Komunitas Perdesaan 
Tabel 9. Skor Rata-rata Tingkat Pengeluaran Menurut Kategori Sosial

\begin{tabular}{|c|c|c|c|c|}
\hline \multirow[b]{2}{*}{ No } & \multirow[b]{2}{*}{ Kategori Sosial } & \multicolumn{2}{|c|}{$\begin{array}{c}\text { Skor Rata-rata Pengeluaran (Rp/Bulan) } \\
\text { Menuut Kategon Sosial }\end{array}$} & \multirow[b]{2}{*}{$A \cdot B$} \\
\hline & & $\begin{array}{l}\text { Anggota } \\
\text { Kelompok Simpan } \\
\text { Pinjam } \\
\text { (A) }\end{array}$ & $\begin{array}{l}\text { Non-Anggota } \\
\text { Kelompok Simpan } \\
\text { Pinjam } \\
\text { (B) }\end{array}$ & \\
\hline 1 & Farm Pengusaha & 844000 & 416700 & 427300 \\
\hline 2 & Non-Farm Penguaha & 1220000 & 450000 & 770000 \\
\hline 3 & Farm Bunh & 641700 & 410000 & 231700 \\
\hline 4 & Non-Farm Bunh & 975000 & 633300 & 341700 \\
\hline
\end{tabular}

Data pada tabel menunjukkan bahwa semua kategori sosial dari 30 responden yang merupakan anggota kelompok simpan pinjam LKMS Kartimi memiliki delta yang positif. Aspek tingkat pendapatan memiliki keterkaitan yang erat dengan aspek tingkat pengeluaran. Sebuah rumah tangga dengan tingkat pendapatan yang tinggi namun pengeluaran juga tinggi, bahkan defisit, tidak lebih baik dibandingan rumah tangga dengan tingkat pendapatan yang rendah namun pengeluaran juga rendah. Dalam hal ini dapat diamati bahwasanya kategori anggota kelompok simpan pinjam yang berlatarbelakang pengusaha baik dari sektor farm maupun non-farm memiliki kecenderungan sama-sama tidak memperoleh dampak positif dalam hal tingkat pendapatan oleh penyelenggaraan program ini. Sejalan dengan data tersebut, pada kenyataannya penyelenggaraan program ini menunjukkan delta yang positif dalam aspek tingkat pengeluaran pada kedua kategori sosial tersebut. Berbeda halnya dengan kategori sosial farm/buruh dan nonfarm/buruh, dimana kedua kategori sosial tersebut samasama memperoleh dampak peningkatan pendapatan oleh penyelenggaraan program tersebut. Meskipun demikian, peningkatan pendapatan oleh kategori sosial ini, memiliki kecenderungan diiringi pula oleh peningkatan pengeluaran. Peningkatan pengeluaran dimungkinkan terjadi karena beberapa hal, yakni faktor internal seperti pengeluaran pribadi dalam rumah tangga yang meningkat, pengeluaran untuk usaha baru atau juga pengembangan usaha yang lama, dan juga faktor eksternal seperti kebutuhan dari luar yang mendadak.

Aspek tingkat pendapatan dan tingkat pengeluaran, memiliki keterkaitan dengan aspek tabungan/saving. Sejauhmana anggota kelompok simpan pinjam LKMS Kartini dapat mengatur keuangan rumah tangga mereka, dan berpikir progressive dengan menyisakan sebagian pendapatan untuk tujuan masa depan. Sebuah rumah tangga, meskipun memiliki tingkat pengeluaran yang besar namun diimbangi tabungan yang juga besar,akan memiliki prospek yang lebih baik dibandingkan dengan yang berpengeluaran sedikit namun tidak menabung. Begitu pun juga dengan rumah tangga yang memiliki pendapatan yang kecil namun secara rutin menabung, akan memiliki perencanaan keuangan untuk masa depan yang lebih baik dibandingkan dengan sebuah rumah tangga yang memiliki pendapatan besar namun tidak mengalokasikan sebagian pendapatannya secara rutin untuk ditabung. Berikut adalah tabel yang menunjukkan bagaimana dampak penyelenggaraan program terhadap tingkat tabungan rumah tangga anggota kelompok simpan pinjam menurut kategori sosial:

Tabel 10. Skor Rata-rata Tingkat Tabungan Menurut Kategori Sosial

\begin{tabular}{|c|l|r|r|r|}
\hline \multirow{2}{*}{ No } & \multirow{2}{*}{ Kategon Sosial } & $\begin{array}{r}\text { Skor Rata-rata Tabungan (Rp/Bulan) Menurut } \\
\text { Kategon Sosial }\end{array}$ & \multirow{2}{*}{ A-B } \\
\cline { 3 - 5 } & & $\begin{array}{r}\text { Anggota Kelompok } \\
\text { Simpan Pinjam (A) }\end{array}$ & $\begin{array}{c}\text { Non-Anggota } \\
\text { Kelompok Simpan } \\
\text { Pinjam (B) }\end{array}$ & \\
\hline 1 & Farm Pengusaha & 606700 & 10000 & 596700 \\
\hline 2 & Non-Farm Pengusaha & 146000 & 0 & 146000 \\
\hline 3 & Farm Buruh & 6700 & 5000 & 1700 \\
\hline 4 & Non-Farm Bunuh & 46500 & 73300 & .26800 \\
\hline
\end{tabular}

Data pada tabel di atas menunjukkan bahwa dari 30 orang responden yang merupakan anggota kelompok simpan pinjam LKMS Kartini dengan kategori sosial Farm/Pengusaha, Non-Farm/Pengusaha, Farm/Buruh memiliki nilai delta yang positif pada variabel tingkat tabungan. Itu artinya anggota kelompok pada ketiga kategori sosial tersebut memiliki kemampuan untuk menyisihkan sebagian uangnya dengan cara ditabung dibandingkan non-anggota kelompok pada kategori sosial tersebut. Sedangkan untuk data kategori sosial NonFarm/Buruh menunjukkan nilai delta yang negatif, dimana itu artinya anggota kelompok kategori tersebut memiliki rata-rata tingkat tabungan yang lebih rendah dibanding non-anggota kelompok pada kategori tersebut. Jika dikaitkan dengan penjelasan aspek dampak ekonomi pada tingkat pendapatan dan juga tingkat pengeluaran di atas, dapat dilihat bahwasanya kategori sosial nonfarm/pengusaha dan farm/pengusaha, meskipun keduanya memiliki nilai delta negatif pada peningkatan pendapatan, namun dalam dilihat dari data pada tingkat tabungan, kedua kategori sosial tersebut sama-sama memiliki nilai delta positif. Itu artinya, meskipun tidak terjadi peningkatan pendapatan oleh penyelenggaraan program ini, dari aspek tabungan kategori sosial tersebut mengalami peningkatan. Secara umum, keterlibatan anggota kelompok simpan pinjam pada penyelenggaraan program pemberdayaan ekonomi lokal melalui kegiatan simpan pinjam LKMS Kartini memberi dampak pada tingkat ekonomi anggotanya tapi tidak pada seluruh aspek dan tidak pada seluruh kategori sosial.

Dampak sosial didefinisikan sebagai perubahan yang dirasakan oleh anggota kelompok simpan pinjam setelah terlibat dalam penyelenggaraan program pada variabel kepercayaan (trust), variabel kerjasama (cooperation), dan variabel jejaring (networking). Dampak sosial dalam hal ini dapat dilihat dengan menghitung senjang/delta dari skor total variabel-variabel dalam modal sosial. Tingkat kepercayaan didefinisikan sebagai perasaan tanpa saling curiga, cenderung saling ingin memajukan diantara anggota masyarakat. Pengukuran tingkat kepercayaan didasarkan pada kepercayaan antara masyarakat, baik anggota kelompok simpan pinjam maupun non-anggota kelompok simpan pinjam. Variabel kedua pada dampak pengukuran adalah kekuatan kerjasama yang didefinisikan sebagai sebuah kondisi dimana di dalam masyarakat terdapat norma-norma untuk bekerjasama, bukan bekerja sendiri. Sikap-sikap kooperatif, keinginan untuk membaktikan diri, akomodatif, menerima tugas dan 
penugasan untuk kemaslahatan bersama, keyakinan bahwa kerjasama akan menguntungkan, yakni antar masyarakat baik anggota kelompok simpan pinjam maupun non-anggota kelompok simpan pinjam. Variabel ketiga adalah kekuatan jaringan yang didefinisikan sebagai interaksi dan relasi individu masyarakat dengan individu lain dalam masyarakat maupun pihak eksternal. Pengukurannya didasarkan pada kekuatan solidaritas dan kerjasama yang terbentuk sebagai hasil dari interaksi sosial tersebut.

Berikut adalah tabel yang menggambarkan perbandingan variabel-variabel modal sosial antara anggota kelompok simpan pinjam dan non-anggota kelompok simpan pinjam menurut kategori sosial:

Tabel 11. Skor Rata-rata Kekuatan Modal Sosial Menurut Kategori Sosial

\begin{tabular}{|c|c|c|c|c|}
\hline \multirow[b]{2}{*}{ No } & \multirow[b]{2}{*}{ Kategori Sosial } & \multicolumn{2}{|c|}{$\begin{array}{l}\text { Skor Rata-rata Modal Sosial } \\
\text { Menurut Kategori Sosial }\end{array}$} & \multirow[b]{2}{*}{$A \cdot B$} \\
\hline & & $\begin{array}{l}\text { Anggota Kelompok } \\
\text { Simpan Pimjam (A) }\end{array}$ & $\begin{array}{l}\text { Non-Angegota Kelompolk } \\
\text { Simpan Pimjam } \\
\text { (B) }\end{array}$ & \\
\hline 1 & Farm/Pengusaha & 48.51 & 48.33 & 0.18 \\
\hline 2 & Non-FarmPengusaha & 49.6 & 57 & $-6,4$ \\
\hline 3 & FarmBuruh & 47.44 & 44.73 & 2.71 \\
\hline 4 & Non-FarmBundh & 50.63 & 41.94 & 8.69 \\
\hline
\end{tabular}

Penyelenggaraan kegiatan kelompok simpan pinjam oleh LKMS Kartini memberi dampak pada modal sosial anggota kelompok simpan pinjam ketika selisih nilai antara anggota kelompok simpan pinjam dan non-anggota kelompok simpan pinjam bernilai positif. Namun pada kenyataannya tidak semua kategori sosial anggota kelompok memiliki nilai positif untuk selisih nilai modal sosial. Data pada tabel di atas menunjukkan bahwasanya dari 30 responden penelitian, anggota kelompok simpan pinjam kategori Non-Farm/Pengusaha memiliki nilai selisih negatif, dimana itu artinya penyelenggaraan program pemberdayaan ekonomi lokal melalui kelompok simpan pinjam tidak memberi dampak positif pada kekuatan modal sosial pada kategori sosial tersebut. Namun, untuk tiga kategori sosial lain, yakni Farm/Pengusaha, Farm/Buruh, Non-Farm/Buruh memiliki nilai selisih positif. Itu artinya dalam penyelenggaraan program dimungkinkan memberikan dampak positif pada kekuatan modal sosial anggota kelompok simpan pinjam.

\section{Hubungan antara Tingkat Partisipasi Anggota Kelompok Simpan Pinjam dan Dampak Sosial}

Hipotesis pertama dalam penelitian ini adalah semakin tinggi partisipasi anggota kelompok simpan pinjam dalam penyelenggaraan program CSR maka semakin kuat modal sosial komunitas perdesaan. Berdasarkan hipotesis tersebut, terdapat dua variabel yang akan diukur, yakni variabel tingkat partisipasi, yang dalam hal ini terbagi dalam tingkat partisipasi anggota kelompok simpan pinjam pada tahap perencanaan, pelaksanaan, evaluasi, maupun pelaporan, dan variabel kekuatan modal sosial, mencakup tingkat kepercayaan, kekuatan kerjasama, serta kekuatan jaringan. Melalui perhitungan statistika dengan uji korelasi rank spearman dan menggunakan alat bantu SPSS v .15.0, didapatkan angka korelasi antara variabel tingkat partisipasi (tahap perencanaan) dan variabel kekuatan modal sosial adalah sebesar 0.849. Karena pvalue (Sig.(2-tailed)) > alpha $(0.1=10$ persen $)$ maka terima Ho, artinya tidak ada korelasi antara variabel tingkat partisipasi (tahap perencanaan) dan variabel kekuatan modal sosial. Hubungan antara kedua variabel tersebut tidak berhubungan secara signifikan sehingga semakin tinggi tingkat partisipasi anggota kelompok simpan pinjam pada tahap perencanaan tidak berhubungan pada peningkatan kekuatan modal sosial kelompok simpan pinjam.

Uji kedua dilakukan untuk mengetahui hubungan antara variabel tingkat partisipasi (tahap pelaksanaan) dan variabel kekuatan modal sosial. Berdasarkan hasil perhitungan dan pengujian, didapatkan angka korelasi antara variabel tingkat partisipasi (tahap pelaksanaan) dan variabel kekuatan modal sosial adalah sebesar 0.017. Karena p-value (Sig.(2-tailed)) < alpha $(0.1=10$ persen) maka tolak Ho, artinya ada korelasi antara variable tingkat partisipasi (tahap pelaksanaan) dan variabel kekuatan modal sosial. Terdapat hubungan antara kedua variabel tersebut, sehingga semakin tingggi tingkat partisipasi anggota kelompok simpan pinjam maka semakin tinggi kekuatan modal sosial anggota kelompok simpan pinjam.

Uji ketiga dilakukan untuk mengetahui hubungan antara variabel tingkat partisipasi (tahap evaluasi) dan variabel kekuatan modal sosial. Berdasarkan hasil perhitungan dan pengujian, didapatkan angka korelasi antara variabel tingkat partisipasi (tahap evaluasi) dan variabel kekuatan modal sosial adalah sebesar 0.088. Karena p-value (Sig.(2-tailed)) > alpha $(0.1=10$ persen) maka tolak Ho, artinya ada korelasi antara variabel tingkat partisipasi (tahap evaluasi) dan variabel kekuatan modal sosial. Hubungan antara kedua variabel tersebut bernilai signifikan sehingga semakin tinggi tingkat partisipasi anggota kelompok simpan pinjam pada tahap perencanaan berpengaruh pada peningkatan kekuatan modal sosial anggota kelompok simpan pinjam, begitu pun sebaliknya. Sedangkan untuk penghitungan variabel tingkat partisipasi pada tahap pelaporan dan kekuatan modal sosial, nilai korelasi tidak keluar karena pada tahap pelaporan nilainya sama (1), jadi walaupun kekuatan modal sosial naik turun, dapat diperkiraan tidak ada hubungannya dengan tahap pelaporan.

Selanjutnya adalah uji untuk mengukur hubungan antara tingkat partisipasi pada keseluruhan tahapan penyelenggaraan program dan kekuatan modal sosial. Berdasarkan hasil perhitungan dan pengujian hipotesis di atas, didapatkan angka korelasi antara variabel tingkat partisipasi (tahap perencanaan, tahap pelaksanaan, tahap evaluasi, dan tahap pelaporan) dan variabel kekuatan modal sosial adalah sebesar 0.079. Karena p-value (Sig.(2-tailed)) > alpha $(0.1=10$ persen) maka tolak Ho, artinya ada korelasi antara variabel tingkat partisipasi pada seluruh tahapan dan variabel kekuatan modal sosial. Sebagai pembanding, dilakukan uji statistik terhadap variabel tingkat partisipasi menggunakan kerangka konsep Arnstein (1969) terhadap kekuatan modal sosial

64 Rosyida, Isma. et. al. Partisipasi Masyarakat dan Stakeholder dalam Penyelenggaraan Program Corporate Social Responsibility (CSR) dan Dampaknya terhadap Komunitas Perdesaan 
anggota kelompok simpan pinjam LKMS Kartini untuk melihat korelasi diantara kedua variabel tersebut. Hasil uji statistik menunjukkan angka korelasi sebesar 0.031 . Karena p-value (Sig.(2-tailed)) > alpha $(0.1=10$ persen) maka tolak Ho, artinya ada korelasi antara variabel tingkat partisipasi pada seluruh tahapan dan variabel kekuatan modal sosial. Kedua uji statistik dengan dua kerangka konsep yang berbeda menunjukkan hasil yang sama, dimana semakin tinggi partisipasi anggota kelompok simpan pinjam dalam penyelenggaraan program CSR maka semakin kuat modal sosial yang terbentuk.

Berdasarkan uji korelasi antara variabel tingkat partisipasi pada setiap tahapan penyelenggaraan program dengan dampak sosial menunjukkan bahwasanya hanya tingkat partisipasi pada tahap pelaksanaan dan evaluasi saja yang menunjukkan hubungan signifikan sehingga dalam hal ini keterlibatan anggota kelompok simpan pinjam pada pelaksanaan program mempengaruhi kekuatan modal sosial mereka. Sedangkan pada tahap perencanaan dan pelaporan, kedua variabel tersebut tidak berkorelasi, sehingga itu artinya, partisipasi anggota kelompok pada tahapan tersebut tidak berpengaruh pada kekuatan modal sosial. Ketika variabel tingkat partisipasi secara keseluruhan diuji hubungannya terhadap dampak sosial, baik dengan kerangka Uphoff maupun dengan kerangka Arnstein, diperoleh angka hubungan yang signifikan, itu artinya partisipasi anggota kelompok dalam penyelenggaraan program, baik pada tahap perencanaan, tahap pelaksanaan, tahap evaluasi, dan tahap pelaporan, berhubungan dengan kekuatan modal sosial anggota kelompok simpan pinjam.

Bagaimana tingkat kepercayaan, kekuatan jejaring, serta kekuatan kerjasama antara masyarakat dengan masyarakat lain, maupun masyarakat terhadap pemerintah desa, dan masyarakat terhadap perusahaan geothermal sudah terbentuk sebelum program pemberdayaan ekonomi lokal ini diselenggarakan. Seiring dengan berjalannya waktu, hingga terbentuknya LKMS Kartini yang memfasilitasi terbentuknya kelompok-kelompk simpan pinjam dengan mengutamakan kebersamaan kelompok, dapat meningkatkan kepercayaan diantara masyarakat terhadap para stakeholder. Adanya kumpulan mingguan dan sistem tanggung renteng yang berlaku dalam kelompok memberi peluang bagi mereka untuk lebih merekatkan satu dengan lainnya. Meskipun demikian, sejauhmana keterlibatan masyarakat dapat membawa dampak bagi kekuatan modal sosial mereka, juga ditentukan oleh individu masingmasing.

\section{Hubungan antara Tingkat Partisipasi Anggota Kelompok Simpan Pinjam dan Dampak Ekonomi}

Hipotesis kedua dalam penelitian ini adalah semakin tinggi partisipasi anggota kelompok simpan pinjam dalam penyelenggaraan program CSR, maka semakin kuat taraf hidup komunitas perdesaan. Berdasarkan hipotesis tersebut, terdapat dua variabel yang akan diukur, yakni variabel tingkat partisipasi, yang dalam hal ini tingkat partisipasi anggota kelompok simpan pinjam dan variabel taraf hidup, mencakup komposit, tingkat pendapatan, tingkat pengeluaran, dan tingkat tabungan. Melalui perhitungan statistika dengan uji korelasi rank spearman dan menggunakan alat bantu SPSS v .15.0, didapatkan angka korelasi antara variabel tingkat partisipasi (tahap perencanaan) dan variabel dampak ekonomi (mencakup tingkat pendapatan, tingkat pengeluaran, tingkat tabungan, dan taraf hidup) adalah sebesar 0.468. Karena p-value (Sig.(2-tailed)) > alpha $(0.1=10$ persen) maka terima Ho, artinya tidak ada korelasi antara variabel ingkat Partisipasi (Tahap Perencanaan) dan Dampak Ekonomi. Hubungan antara kedua variabel tersebut tidak signifikan sehingga itu artinya semakin tinggi tingkat partisipasi masyarakat pada tahap perencanaan tidak berhubungan pada peningkatan tingkat pendapatan, tingkat pengeluaran, tingkat tabungan serta taraf hidup anggota kelompok simpan pinjam LKMS Kartini.

Uji kedua dilakukan untuk mengetahui hubungan antara variabel tingkat partisipasi pada tahap pelaksanaan dan dampak ekonomi atau taraf hidup. Berdasarkan hasil perhitungan dan pengujian hipotesis yang tertera pada tabel diatas, didapatkan angka korelasi antara variabel tingkat partisipasi (tahap pelaksanaan) dan variabel dampak ekonomi (mencakup tingkat pendapatan, tingkat pengeluaran, tingkat tabungan, dan taraf hidup) adalah sebesar 0.215. Karena p-value (Sig.(2-tailed)) > alpha $(0.1=10$ persen $)$ maka terima Ho, artinya tidak ada korelasi antara variabel tingkat partisipasi (tahap perencanaan) dan dampak ekonomi. Hubungan antara kedua variabel tersebut bernilai negatif sehingga semakin tinggi tingkat partisipasi anggota kelompok simpan pinjam pada tahap pelaksanaan tidak berpengaruh pada peningkatan tingkat pendapatan, tingkat pengeluaran, tingkat tabungan serta taraf hidup anggota kelompok simpan pinjam.

Uji ketiga dilakukan untuk mengetahui hubungan antara variabel tingkat partisipasi pada tahap evaluasi dan dampak ekonomi atau taraf hidup. Berdasarkan hasil perhitungan dan pengujian, didapatkan angka korelasi antara variabel tingkat partisipasi (tahap evaluasi) dan variabel dampak ekonomi (mencakup tingkat pendapatan, tingkat pengeluaran, tingkat tabungan, dan taraf hidup) adalah sebesar 0.245. Karena p-value (Sig.(2-tailed)) > alpha $(0.1=10$ persen $)$ maka terima Ho, artinya tidak ada korelasi antara variabel tingkat partisipasi (tahap evaluasi) dan dampak ekonomi. Hubungan antara kedua variabel tersebut tidak signifikan, sehingga semakin tinggi tingkat partisipasi anggota kelompok simpan pinjam pada tahap evaluasi, tidak behubungan dengan peningkatan tingkat pendapatan, tingkat pengeluaran, tingkat tabungan serta taraf hidup anggota kelompok simpan pinjam.

Uji keempat dilakukan untuk mengetahui hubungan antara variabel tingkat partisipasi pada tahap pelaporan dan dampak ekonomi atau taraf hidup. Berdasarkan hasil perhitungan dan pengujian, nilai korelasi tidak keluar karena pada tahap pelaporan nilainya sama (1), jadi diperkirakan, keterlibatan anggota kelompok simpan pinjam dalam penyelenggaraan program pada tahap pelaporan tidak memiliki korelasi terhadap kondisi ekonomi anggota kelompok simpan pinjam, meliputi tingkat pendapatan, tingkat pengeluaran, tingkat tabungan, dan taraf hidup. Uji terakhir dilakukan untuk mengetahui hubungan antara variabel tingkat partisipasi pada seluruh tahapan penyelenggaraan program dan 
dampak ekonomi. Berdasarkan hasil perhitungan dan pengujian hipotesis yang tertera di atas, didapatkan angka korelasi antara variabel tingkat partisipasi (tahap perencanaan, tahap pelaksanaan, tahap evaluasi, dan tahap pelaporan) dan variabel dampak ekonomi adalah sebesar 0.058. Karena p-value (Sig.(2-tailed)) > alpha $(0.1=10$ persen) maka tolak Ho, artinya ada korelasi antara variabel tingkat partisipasi (tahap evaluasi) dan variabel dampak ekonomi. Sebagai pembanding, dilakukan uji statistik untuk melihat korelasi antara variabel tingkat partisipasi dengan kerangka konsep arnstein dan variabel taraf hidup. Berdasarkan hasil perhitungan dan pengujian hipotesis yang tertera di atas, didapatkan angka korelasi sebesar 0.006, yang mana berarti terdapat hubungan yang signifikan diantara dua variabel tersebut. Uji statistik yang dilakukan dengan kerangka konsep Uphoff maupun Arnstein menunjukkan bahwa kedua variabel berkorelasi dengan signifikan. Jadi semakin tinggi partisipasi anggota kelompok simpan pinjam dalam penyelenggaraan program CSR maka semakin kuat taraf hidup komunitas perdesaan.

Hasil pengolahan data mengenai hubungan antara tingkat partisipasi dengan dampak ekonomi, baik dengan kerangka konsep Uphoff (1979) maupun konsep Arnstein (1969) menunjukkan bahwasanya tingkat partisipasi anggota kelompok simpan pinjam memiliki hubungan korelasi yang signifikan terhadap dampak ekonomi. Itu artinya bahwa semakin tinggi tingkat partisipasi anggota kelompok simpan pinjam, maka semakin tinggi pula dampak ekonomi yang akan diperoleh oleh anggota kelompok simpan pinjam. Meskipun demikian, hasil pengolahan data juga menunjukkan bahwasanya hubungan antara tingkat partisipasi pada setiap tahapan, yakni tahap perencanaan, pelaksanaan, evaluasi, dan pelaporan, masing-masing tidak memiliki korelasi positif dengan dampak ekonomi. Itu artinya, dalam melihat hubungan antara tingkat partisipasi dengan dampak ekonomi tidak dapat dipisahkan secara parsial tiap-tiap tahapan penyelenggaraan program. Suatu program akan memiliki dampak yang lebih nyata, ketika setiap stakeholder berpartisipasi pada setiap tahapan penyelenggaraan.

\section{Analisis dan Sintesis Partisipasi Stakeholder dalam Penyelenggaraan Corporate Social Responsibility (CSR) dan Dampaknya terhadap Komunitas Perdesaan}

Perusahaan Geothermal tidak berjalan sendiri dalam menyelenggarakan program pemberdayaan ekonomi lokal melalui pembentukan LKMS Kartini, melainkan menggandeng mitra yakni Permodalan Nasional Madani, sebuah perusahaan BUMN yang bergerak di bidang konsultan ekonomi. Antara Perusahaan Geothermal dengan mitranya membentuk kesepakatan kerjasama dan kemitraan dalam pelaksanaan program ini. Masyarakat juga terlibat dalam penyelenggaraan LKMS Kartini, baik yang tergolong sebagai pengurus LKMS Kartini, maupun sebagai anggota LKMS Kartini (anggota kelompok ibuibu simpan pinjam). Pemerintah Desa dan Kecamatan juga memiliki keterlibatan dalam penyelenggaraan LKMS Kartini beserta Dinas Koperasi sebagai representasi dari pemerintah. Berikut adalah skema yang menjelaskan bagaimana hubungan antar stakeholder dalam penyelenggaraan program pemberdayaan ekonomi lokal melalui pembentukan LKMS Kartini:

Skema di atas menjelaskan bagaimana keterkaitan antar stakeholder yang terlibat dalam penyelenggaraan LKMS Kartini. Hubungan dengan garis panah lurus menjelaskan bahwa terdapat hubungan langsung antara kedua stakeholder, sedangkan hubungan dengan garis lurus putus-putus menjelaskan bahwa hubungan antara kedua stakeholder tersebut tidak secara langsung.

Hubungan antar stakeholder dalam penyelenggaraan LKMS Kartini terkait dengan sejauhmana masing-masing stakeholder terlibat atau berpartisipasi dalam setiap tahapan penyelenggaraan program, baik pada tahapan perencanaan, pelaksanaan, evaluasi, dan pelaporan. Partisipasi masyarakat menggambarkan bagaimana terjadinya pembagian ulang kekuasaan yang adil (redistribution of power) antara penyedia kegiatan dan kelompok penerima kegiatan. Partisipasi masyarakat tersebut bertingkat, sesuai dengan gradasi, derajat wewenang dan tanggung jawab yang dapat dilihat dalam proses pengambilan keputusan (Arnstein 1986 dalam Wicaksono 2010).

Aspek-aspek dalam derajat keterlibatan/partisipasi menentukan tipe partisipasi stakeholder yang dianalisis menggunakan konsep Tangga Partisipasi Arnstein. Di bawah ini adalah matriks keterlibatan/partisipasi Stakeholder pada setiap tahapan berikut tipe partisipasi yang dianalisis menggunakan Tangga Partisipasi Arnstein.

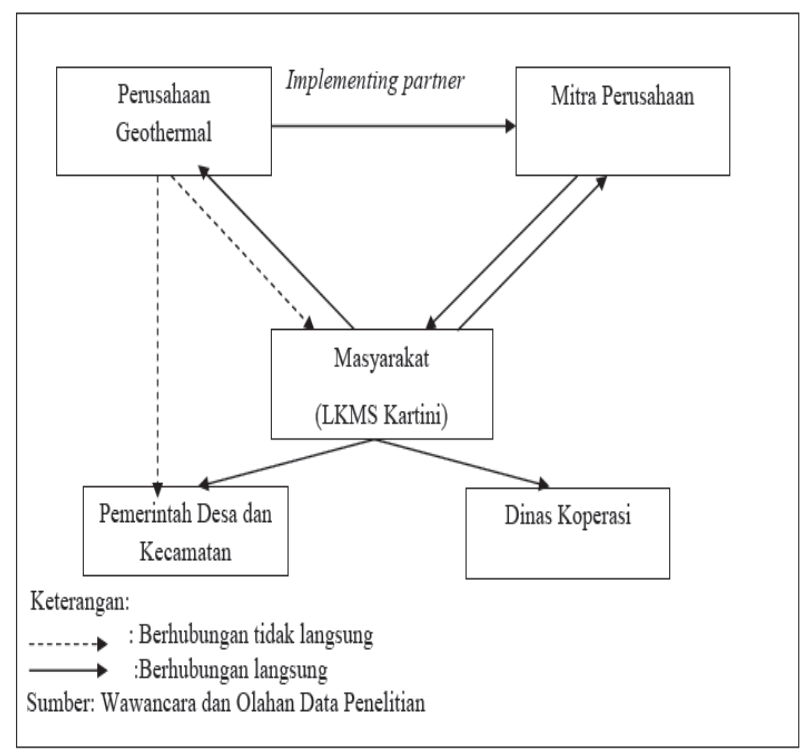

Gambar 5. Skema Alur Hubungan antara Stakeholder dalam Penyelenggaraan 


\begin{tabular}{|c|c|c|c|c|c|}
\hline & $\begin{array}{c}\text { Tahap } \\
\text { Perencanaan }\end{array}$ & $\begin{array}{c}\text { Thahap } \\
\text { Pelalssanaan }\end{array}$ & $\begin{array}{l}\text { Tahapp } \\
\text { Evaduasi }\end{array}$ & $\begin{array}{l}\text { Talapp } \\
\text { Pelaporan }\end{array}$ & $\begin{array}{l}\text { Tipe Partisipasi } \\
\text { Menunt Tangga } \\
\text { Partisipasi Arstein }\end{array}$ \\
\hline $\begin{array}{l}\text { Masyarakat } \\
\text { (Pengurus } \\
\text { Koperasi) }\end{array}$ & $\begin{array}{l}\text { Terlibat } \\
\text { (Rendah) }\end{array}$ & $\begin{array}{l}\text { Terlibat } \\
\text { (Iinggi) }\end{array}$ & $\begin{array}{l}\text { Terlibat } \\
\text { (Timggei) }\end{array}$ & $\begin{array}{l}\text { Terlibat } \\
\text { (Iimgge) }\end{array}$ & $\begin{array}{l}\text { Tipe Penentraman } \\
\text { (Tokenism) }\end{array}$ \\
\hline $\begin{array}{l}\text { Masyarakat } \\
\text { (Anggota } \\
\text { Koperasi) }\end{array}$ & Tidalak Terilibat & $\begin{array}{l}\text { Terlibat } \\
\text { (Sedangg) }\end{array}$ & $\begin{array}{l}\text { Terilibat } \\
\text { (Rendah) }\end{array}$ & Tiddak terlibat & $\begin{array}{l}\text { Tipe Pembentahuan } \\
\text { Tipe Konsultasi } \\
\text { Tipe Penentraman } \\
\text { (Tokenism) }\end{array}$ \\
\hline $\begin{array}{l}\text { Pemerintah } \\
\text { Desa dan } \\
\text { Kecamatan }\end{array}$ & Tidalak Terilibat & Tidak Terilibat & $\begin{array}{l}\text { Terilibat } \\
\text { (Rendah) }\end{array}$ & Tidak Terlibat & $\begin{array}{c}\text { Tipe Terapi } \\
\text { (Taupa Partisipasi) }\end{array}$ \\
\hline $\begin{array}{l}\text { Perusahhan } \\
\text { Geothermal }\end{array}$ & $\begin{array}{l}\text { Terlibat } \\
\text { (Timgge) }\end{array}$ & $\begin{array}{l}\text { Tertibat } \\
\text { (Rendah) }\end{array}$ & $\begin{array}{l}\text { Terlibat } \\
\text { (Sedang) }\end{array}$ & $\begin{array}{l}\text { Terlibat } \\
\text { (Sedang) }\end{array}$ & $\begin{array}{l}\text { Tipe Kemitraan } \\
\text { (Parhinership) }\end{array}$ \\
\hline $\begin{array}{c}\text { litrn } \\
\text { Perushlana } \\
\text { (PNM) }\end{array}$ & $\begin{array}{l}\text { Terlibat } \\
\text { (Timgge') }\end{array}$ & $\begin{array}{l}\text { Terilibat } \\
\text { (Iingegi) }\end{array}$ & $\begin{array}{l}\text { Terilibat } \\
\text { (Tinggi) }\end{array}$ & $\begin{array}{l}\text { Terlibat } \\
\text { (Tinggi) }\end{array}$ & $\begin{array}{l}\text { Tipe Kemitraan } \\
\text { (Parthershipip) }\end{array}$ \\
\hline Dinas Koperasi & $\begin{array}{l}\text { Terlibat } \\
\text { (Rendah) }\end{array}$ & $\begin{array}{l}\text { Tidak } \\
\text { Teribat }\end{array}$ & $\begin{array}{l}\text { Tidala } \\
\text { Terilibat }\end{array}$ & Tidak Terlibat & $\begin{array}{c}\text { Tipe Pembentaluan } \\
\text { (Tokenism) }\end{array}$ \\
\hline
\end{tabular}

\section{Gambar 6. Matriks Keterlibatan Stakeholder dalam Penvelengoaranan LKMS Kartini}

Masing-masing stakeholder memiliki derajat partisipasi yang berbeda-beda dalam penyelenggaraan LKMS Kartini. Tingkat partisipasi tertinggi terletak pada perusahaan geothermal, mitra perusahaan, dan pengurus koperasi, tingkat partisipasi sedang terletak pada anggota kelompok simpan pinjam, dan tingkat partisipasi rendah terdapat pada pemerintah desa dan kecamatan, serta Dinas Koperasi. Banyak faktor yang berpengaruh terhadap sejauhmana tingkat partisipasi masyarakat, khususnya anggota kelompok simpan pinjam terhadap penyelenggaraan program.

Variabel Tingkat Partisipasi diukur berdasarkan intensitas keterlibatan anggota kelompok simpan pinjam berikut sejauhmana peran dan fungsi anggota kelompok simpan pinjam, tingkat pelibatan anggota kelompok simpan pinjam dalam pengambilan keputusan dalam program juga dijadikan dasar dalam menganalisis tingkat partisipasi anggota kelompok simpan pinjam terhadap kegiatan dalam tahapan penyelenggaraan program yang dilaksanakannya, baik pada tahap perencanaan, tahap pelaksanaan, tahap evaluasi, maupun tahap pelaporan. Dalam penelitian ini, anggota kelompok simpan pinjam dikategorikan berdasarkan tipe mata pencahariannya menjadi empat kategori sosial, yakni farm/pengusaha, non-farm/pengusaha, farm/buruh, dan non-farm/buruh. Analisis frekuensi skor tingkat partisipasi dengan kerangka konsep Uphoff (1979) Menunjukkan bahwasanya kategori sosial 4 yaitu kategori sosial nonfarm/buruh memiliki keterlibatan paling tinggi dalam penyelenggaraan program pemberdayaan ekonomi lokal melalui kegiatan simpan pinjam koperasi, sedangkan kategori sosial 3 yaitu kategori sosial farm/buruh memiliki keterlibatan yang paling rendah dalam partisipasi terhadap program. Kategori sosial 1 dan Kategori sosial 2 cenderung memiliki tingkat partisipasi yang sedang. Masyarakat dari sektor mata pencaharian non-farm memiliki kecenderungan keterlibatan/partisipasi yang lebih tinggi dibanding masyarakat dari sektor farm. Analisis juga dilakukan dengan kerangka konsep Arnstein (1969) dimana hasil frekuensi dan penghitungan skor menunjukkan bahwasanya sebagian besar anggota kelompok simpan pinjam berpartisipasi hingga tingkat tokenism, atau dalam hal ini hingga tipe pemberitahuan dan konsultasi. Dalam hal ini, anggota kelompok simpan pinjam hanya diarahkan untuk menerima informasi melalui sosialisasi dan jikalau ada saran, hanya sekedar didengar atau diterima, namun tidak untuk dilaksanakan. Oleh karena itu, keterlibatan anggota kelompok simpan pinjam di Desa Cihamerang tergolong rendah menuju sedang dengan tingkat kekuasaan pada level tokenism, yakni berorientasi pada justifikasi masyarakat agar mengiyakan segala sesuatu yang telah dirancang sehingga anggota kelompok simpan pinjam tidak memiliki kontrol untuk mengambil keputusan.

Sejauhmana program pemberdayaan ekonomi lokal melalui penyelenggaraan LKMS Kartini dapat berimplikasi dan berkontribusi terhadap seluruh stakeholder, khususnya anggota kelompok simpan pinjam, adalah ketika dapat dilihat dampak dari penyelenggaraan program, baik dari sisi ekonomi maupun sosial. Penelitian ini mencoba melihat bagaimana hubungan atau korelasi antara tingkat partisipasi atau tingkat keterlibatan stakeholder, khususnya anggota kelompok simpan pinjam, pada setiap tahapan penyelenggaraan program terhadap dampak sosial dan dampak ekonomi program yang mereka peroleh. Dampak sosial didefinisikan sebagai perubahan yang dirasakan oleh anggota kelompok simpan pinjam setelah terlibat dalam penyelenggaraan program pada variabel kepercayaan (trust), variabel kerjasama (cooperation), dan variabel jejaring (networking). Hasil pengolahan data baik dengan kerangka konsep partisipasi menurut Uphoff (1979), maupun Arnstein (1969), menunjukkan bahwa diperoleh hubungan antara variabel tingkat partisipasi dengan dampak sosial yang signifikan. Hal tersebut menunjukkan bahwa partisipasi anggota kelompok simpan pinjam secara keseluruhan dalam penyelenggaraan program berhubungan dengan kekuatan modal sosial dalam masyarakat tersebut. Uji korelasi antara variabel tingkat partisipasi pada setiap tahapan dengan dampak sosial menunjukkan bahwasanya tingkat partisipasi pada tahap pelaksanaan dan evaluasi menunjukkan hubungan korelasi sehingga dalam hal ini keterlibatan anggota kelompok simpan pinjam pada pelaksanaan program mempengaruhi kekuatan modal sosial mereka. Pada tahap perencanaan dan pelaporan, kedua variabel tersebut tidak berkorelasi, sehingga itu artinya partisipasi anggota kelompok simpan pinjam pada tahapan tersebut tidak berpengaruh pada kekuatan modal sosial. Penyelenggaraan LKMS Kartini memberi dampak pada modal sosial anggota kelompok simpan pinjam ketika selisih nilai antara anggota kelompok simpan pinjam dan non-anggota kelompok simpan pinjam, namun tidak semua kategori sosial anggota kelompok simpan pinjam memperoleh dampak sosial. Hal tersebut dijelaskan melalui hasil penelitian bahwasanya anggota kelompok simpan pinjam kategori non-farm/pengusaha memiliki nilai selisih negatif, dimana itu artinya keterlibatannya dalam penyelenggaraan program 
pemberdayaan ekonomi lokal melalui kelompok simpan pinjam tidak memberi dampak positif. Namun, untuk tiga kategori sosial lain, yakni farm/pengusaha, farm/buruh, non-farm/buruh memiliki nilai selisih positif. Itu artinya keterlibatan anggota kelompok simpan pinjam pada kategori tersebut dalam penyelenggaraan program dimungkinkan memberikan dampak positif bagi kekuatan modal sosial anggota kelompok simpan pinjam.Sejalan dengan pembuktian terhadap hipotesis pertama, hasil pengolahan data menunjukkan bahwa tingkat partisipasi anggota kelompok simpan pinjam, baik dengan kerangka konsep partisipasi menurut Uphoff (1979) dan Arnstein (1969), memiliki hubungan korelasi yang signifikan terhadap dampak ekonomi. Itu artinya bahwa semakin tinggi tingkat partisipasi anggota kelompok simpan pinjam, maka semakin tinggi pula dampak ekonomi yang akan diperoleh oleh anggota kelompok simpan pinjam.

Hasil pengolahan data juga menunjukkan bahwasanya hubungan antara tingkat partisipasi pada setiap tahapan, yakni tahap perencanaan, pelaksanaan, evaluasi, dan pelaporan, masing-masing tidak memiliki korelasi positif dengan dampak ekonomi. Itu artinya, dalam melihat hubungan antara tingkat partisipasi dengan dampak ekonomi tidak dapat dipisahkan secara parsial tiap-tiap tahapan penyelenggaraan program. Keterlibatan anggota kelompok simpan pinjam dalam penyelenggaraan belum tentu menentukan peningkatan taraf hidup anggota kelompok simpan pinjam pada semua kategori karena hasil penelitian menunjukkan bahwa Kategori sosial nonfarm/pengusaha dan non-farm/buruh memiliki dampak positif dalam taraf hidup terhadap penyelenggaraan LKMS Kartini, sedangkan dampak taraf hidup negatif dapat dilihat pada kategori sosial farm/pengusaha dan farm/buruh, tidak semua kategori sosial memperoleh dampak positif dalam tingkat pendapatan terhadap penyelenggaraan LKMS Kartini, dapat dilihat bahwa keterlibatan dalam program ini tidak memberikan dampak bagi pendapatan anggota kelompok simpan pinjam dari kategori sosial farm/pengusaha dan non-farm/pengusaha, sedangkan anggota kelompok simpan pinjam dari kategori sosial farm/buruh dan non-farm/buruh memperoleh dampak bagi pendapatan rumah tangganya. Aspek tingkat pendapatan memiliki keterkaitan yang erat dengan aspek tingkat pengeluaran. Sebuah rumah tangga dengan tingkat pendapatan yang tinggi namun pengeluaran juga tinggi, bahkan defisit, tidak lebih baik dibandingkan rumah tangga dengan tingkat pendapatan yang rendah namun pengeluaran juga rendah. Dari keempat kategori sosial, seluruhnya memiliki nilai delta yang positif dalam aspek tingkat pengeluaran. Antara aspek tingkat pendapatan dan tingkat pengeluaran, memiliki keterkaitan dengan aspek tabungan/saving. Anggota kelompok simpan pinjam dengan kategori sosial farm/pengusaha, nonfarm/pengusaha, farm/buruh memiliki dampak positif terhadap tingkat tabungan rumah tangga. Keterlibatan anggota kelompok simpan pinjam dalam kelompok simpan pinjam membuat kategori masyarakat tersebut dapat mengatur keuangan rumah tangga mereka, dan berpikir progressive dengan menyisakan sebagian pendapatan untuk masa depan.

Suatu program akan memiliki dampak yang lebih nyata, ketika setiap stakeholder berpartisipasi pada setiap tahapan penyelenggaraan. Partisipasi atau keterlibatan anggota kelompok simpan pinjam dalam penyelenggaraan program pemberdayaan ekonomi lokal melalui kegiatan simpan pinjam LKMS Kartini memberi dampak pada tingkat ekonomi anggota kelompok simpan pinjam.. Kategori sosial non-farm/Buruh memiliki tingkat partisipasi yang paling tinggi diantara kategori sosial yang lain. Hal tersebut ternyata diiringi dengan dampak sosial ekonomi yang diperoleh kategori sosial tersebut, dimana tingkat pastisipasi masyarakat dari kategori sosial non-farm/buruh memberi dampak positif pada taraf hidup, tingkat pendapatan, kekuatan modal sosial. Kategori sosial anggota kelompok simpan pinjam farm/buruh memiliki tingkat partisipasi yang paling rendah diantara kategori sosial yang lain. Keikutsertaan anggota kelompok simpan pinjam kategori sosial tersebut sejalan dengan kondisi taraf hidup karena tidak ada nilai peningkatan taraf hidup setelah mengikuti kegiatan simpan pinjam. Meskipun demikian, tingkat partisipasi masyarakat dengan kategori sosial tersebut memiliki hubungan terhadap tingkat pendapatan, tingkat tabungan, dan kekuatan modal sosial. Untuk kategori Nonfarm/pengusaha, dan farm/pengusaha, tingkat partisipasi mereka tergolong sedang, namun data menunjukkan bahwa keterlibatan pada kategori sosial tersebut tidak diikuti oleh peningkatan tingkat pendapatan, tingkat tabungan serta kekuatan modal sosial, kecuali untuk variabel taraf hidup, karena data menunjukkan bahwa terdapat peningkatan taraf hidup pada kategori Nonfarm/pengusaha. Dengan memandirikan masyarakat melalui penyelenggaraan program pemberdayaan ekonomi lokal maka masyarakat dapat secara mandiri mengembangkan perekonomiannya di tingkat rumah tangga dan tidak perlu bergantung terus kepada Perusahaan Geothermal.

\section{PENUTUP}

\section{Kesimpulan}

Penyelenggaraan LKMS Kartini merupakan salah satu wujud penyelenggaraan program CSR Perusahaan Geothermal yang berfokus pada area pemberdayaan ekonomi lokal. Hasil penelitian menunjukkan bahwa tingkat partisipasi anggota kelompok simpan pinjam di Desa Cihamerang dalam penyelenggaraan program pemberdayaan ekonomi lokal berhubungan dengan dampak sosial dan ekonomi masyarakat, sehingga jika partisipasi anggota kelompok simpan pinjam dalam penyelenggaraan program tinggi, maka dampak sosial dan ekonomi juga akan tinggi. Sejauhmana dampak sosial ekonomi diperoleh anggota kelompok simpan pinjam juga ditentukan oleh partisipasi dari stakeholder lain yang terkait. Jika dilihat dari klasifikasi kategori sosial yang ada, masyarakat dengan kategori sosial farm/buruh memiliki tingkat partisipasi yang paling rendah diantara kategori sosial yang lain. Keikutsertaan anggota kelompok simpan pinjam kategori sosial tersebut, sejalan dengan kondisi taraf hidup anggota kelompok simpan pinjam karena tidak ada nilai peningkatan taraf hidup setelah mengikuti kegiatan simpan pinjam. Meskipun demikian, tingkat partisipasi pada kategori sosial tersebut memiliki hubungan terhadap tingkat pendapatan, tingkat tabungan, dan kekuatan modal sosial. Untuk kategori

68 Rosyida, Isma. et. al. Partisipasi Masyarakat dan Stakeholder dalam Penyelenggaraan Program Corporate Social Responsibility (CSR) dan Dampaknya terhadap Komunitas Perdesaan 
anggota kelompok simpan pinjam non-farm/pengusaha, dan farm/pengusaha tingkat partisipasi mereka tergolong sedang, namun data menunjukkan bahwa keterlibatan masyarakat pada kategori sosial tersebut tidak diikuti oleh peningkatan tingkat pendapatan, tingkat tabungan serta kekuatan modal sosial, kecuali untuk variabel taraf hidup, karena data menunjukkan bahwa terdapat peningkatan taraf hidup pada masyarakat kategori nonfarm/pengusaha.

Penyelenggaraan program pemberdayaan ekonomi lokal secara langsung dan langsung membawa dampak pada kondisi sosial ekonomi anggota kelompok simpan pinjam pada khususnya. Hal tersebut juga dipengaruhi oleh sejauhmana anggota kelompok simpan pinjam turut berpartisipasi dalam penyelenggaraannya. Dalam hal ini, tingkat keterlibatan masing-masing stakeholder memiliki tingkatan yang berbeda-beda. Pada pelaksanaannya, penyelenggaraan program ini didominasi oleh peran dan fungsi Perusahaan Geothermal sebagai penyandang dana sekaligus pengambil keputusan pada awal pendirian. Stakeholder lain memiliki derajat keterlibatan yang rendah dengan peran dan fungsi yang berbeda. Masyarakat, yang dalam hal ini seharusnya secara aktif terlibat sebagai subjek dalam program, belum sepenuhnya terlibat sebagaimana mestinya. Begitu pun dengan pihak pemerintah lokal yang seharusnya dapat turut berpartisipasi dalam mendukung penyelenggaraan program, sejauh ini tidak terlibat secara langsung. Dominansi keterlibatan pihak swasta dalam penyelenggaraan program mempengaruhi sejauhmana program pemberdayaan berlangsung. Sejauhmana partisipasi anggota kelompok simpan pinjam berhubungan dengan dampak sosial ekonomi yang diperoleh juga dipengaruhi oleh faktor keterlibatan stakeholder lain.

\section{Saran}

Mengacu pada hasil penelitian, maka terdapat beberapa hal yang dapat dijadikan masukan atau saran, diantaranya:

1. Sebaiknya Perusahaan Geothermal melakukan pendekatan partisipatif terhadap masyarakat dan pemerintah, begitu pun pemerintah dan masyarakat terhadap Perusahaan Geothermal sehingga tercipta hubungan yang lebih harmonis, saling mempercayai satu sama lain dan dapat membangun kerjasama yang baik.

2. LKMS Kartini sebaiknya mulai diarahkan untuk mengubah orientasi kegiatan yang hanya berfokus pada tingkat pengembalian dalam pembiayaan LKMS, melainkan orientasi perlu diarahkan pada sejauhmana pencapaian perguliran dana masing rumah tangga dalam pemanfaatan modal usaha.

3. Kebijakan pemerintah lokal dapat disinergikan dengan keberadaan perusahaan, sehingga penyelenggaraan program yang berkaitan dengan pengembangan masyarakat tidak tumpang tindih dan secara penuh melibatkan stakeholder terkait

\section{DAFTAR PUSTAKA}

Ambadar, Jackie. 2008. CSR dalam Praktik di Indonesia. Jakarta: PT Elex Media Komputindo.

Anonim, 2008. Annual Report Perusahaan Geothermal. Jakarta: Perusahaan Geothermal.

Anonim, 2009. Annual Report Perusahaan Geothermal. Jakarta: Perusahaan Geothermal.

Arnstein, Sherry R. 1969. A Ladder Warga Negara Partisipasi. http://lithgow-schmidt.dk/sherryarnstein/ladder-of-citizen-participation.html diakses pada 26 Januari 2011.

Dahlsrud, Alexander. How Corporate Social Responsibility is Defined: an Analysis of 37 Definitions. Corporate Social Responsibility and Environmental Management, Volume 15, 2008, hal. 1-13. www.interscience.wiley.com DOI: $10.1002 /$ csr. 132 .

Djohan, Robby. 2007. Lead to togetherness. Fund Asia Eduaction. Jakarta.

Dragicevic, Damir dkk. Reporting on Community Impacts: A survey conducted by the Global Reporting Initiative.Global Reporting Initiative, 2008.

Kriyantono, Rahmat. 2009. Teknik Praktis Riset Komunikasi. Jakarta: Prenada Media Group

Lakin, Nick dan Veronica Scheubel.Corporate Community Involvement: The Definitive Guide to Maximizing Your Business Societal Engagement. Greenleaf Publishing, 2010.

Lee, Min-Dong Paul. A Review of the Theories of Corporate Social Responsibility:Its Evolutionary Path and the Road Ahead. International Journal of Management Reviews Doi : 10.1111/j.14682370.2007.00226.xx, 2008.।

Nasdian, Fredian Tonny. 2006. Pengembangan Masyarakat (Community Development). Bogor: Institut Pertanian Bogor.

Nursahid, Fajar. 2006. Tanggung jawab sosial BUMN: Analisis Terhadap Model Kedermawanan Sosial Krakatau Steel, PT Pertamina dan PT Telekomunikasi Indonesia. Depok: Piramedia.

Rahman, Arief. Implementasi Corporate Social Responsibility sebagai Kenggulan Kompetitif Perusahaan. Jurnal Sinergi (Kajian Bisnis dan Manajemen), Volume 6, No. 2, 2004, hal. 37-46.

Rahman, Reza. 2009. Corporate Social Responsibility: Antara Teori dan KenyataanYogyakarta: Media Pressindo

Pemerintah Desa Cihamerang. 2010. "Profil Desa Cihamerang". Kecamatan Kabandungan. Kabupaten Sukabumi.

Saidi, Zaim dkk. 2003. Sumbangan Sosial Perusahaan :Profil dan Pola Distribusinya di Indonesia Survei 226 Perusahaan di 10 Kota. Jakarta Selatan: Piramedia. 
Singarimbun, Masri. 1995. Metode Penelitian Survai. Jakarta: PT Pustaka LP3ES Indonesia

Sitorus, Felix. 1998. Penelitian Kualitatif "Suatu Perkenalan". Kelompok Dokumentasi Ilmu-ilmu sosial untuk laboratorium Sosiologi, Antropologi dan Kependudukan Jurusan Ilmu sosial dan Ekonomi Pertanian, Fakultas Pertanian IPB.

Soemanto, Bakdi dkk. 2007.Sustainable Corporate : Implikasi Hubungan Harmonis Perusahaan dan Masyarakat.Gresik: PT Semen Gresik (Persero).

Suharto, Edi. 2005. Membangun Masyarakat Memberdayakan Masyarakat "Kajian Strategis Pembangunan Kesejahteraan Sosial dan Pekerjaan Sosial". Bandung :PT Refika Aditama.

Sukada, Sonny dkk. 2007.Membumikan Bisnis Berkelanjutan. Jakarta: Indonesia Business Links.

Uphoff, NT.,Cohen, JM., dan Goldsmith, AA. Rural Development Committee: Feasibility and Application of Rural Development Participation: A. State-of-the-Arth Paper. New York: Cornell University.

Wibisono, Yusuf. 2007. Membedah Konsep dan Aplikasi CSR (Corporate Social Responsibility). Gresik: Fascho Publishing.

Wicaksono, Mohammad Arya. 2010. Analisis Tingkat Partisipasi Warga Dalam Tanggung Jawab Sosial Perusahaan (Studi Kasus: PT Isuzu Astra Motor Indonesia Assy Plant Pondok Ungu). Skripsi. Tidak Diterbitkan. Program Studi Sains Komunikasi dan Pengembangan Masyarakat, Fakultas Ekologi Manusia, Institut Pertanian Bogor. 